\title{
Review
}

\section{Strategic Study for Renewable Energy Policy, Optimizations and Sustainability in Iran}

\author{
Rahim Zahedi (D), Alireza Zahedi and Abolfazl Ahmadi *(D)
}

Citation: Zahedi, R.; Zahedi, A.; Ahmadi, A. Strategic Study for Renewable Energy Policy, Optimizations and Sustainability in Iran. Sustainability 2022, 14, 2418. https://doi.org/10.3390/su14042418

Academic Editor: Donato Morea

Received: 2 February 2022

Accepted: 17 February 2022

Published: 20 February 2022

Publisher's Note: MDPI stays neutral with regard to jurisdictional claims in published maps and institutional affiliations.

Copyright: (C) 2022 by the authors. Licensee MDPI, Basel, Switzerland. This article is an open access article distributed under the terms and conditions of the Creative Commons Attribution (CC BY) license (https:// creativecommons.org/licenses/by/ $4.0 /)$.

\author{
Department of Energy Systems Engineering, School of Advanced Technologies, Iran University of Science \\ and Technology, Tehran 16846-13114, Iran; rahimzahedi@ut.ac.ir (R.Z.); zahediar@iust.ac.ir (A.Z.) \\ * Correspondence: a_ahmadi@iust.ac.ir; Tel.: +98-9124394740
}

\begin{abstract}
The present article includes studies on the importance of addressing strategic issues in the field of general policies adopted and strategies for the development of renewable energy in Iran. Considering that energy is one of the determining indicators in economic development and the development and optimization of renewable energy can play an effective role in economic growth and protection of environmental conditions, this article tries to introduce the types of renewable energy and general principles. They point to the policies that ultimately determine the priority and necessity of using some of them for the country and explain why and how to use them. The general principles discussed in this article include the advantages, disadvantages, potentials, and, most importantly, comparative comparisons with two neighboring countries. The results of these studies show that despite Iran's diverse potentials in the field of renewable energy, wind energy has a higher priority than other cases in terms of economic justification and market competition, and domestic production rates. Other renewable energy sources for power generation and grid connection are less of a priority for short- or medium-term investment. However, for non-grid use in the country, they can also be very useful in the short term. In general, Iran can be a hub for renewable energy.
\end{abstract}

Keywords: renewable energy policies; potential assessment; comparative study; energy optimization; sustainability

\section{Introduction}

The global energy supply system faces problems such as price fluctuations, energy security, and environmental issues. Mankind will face two great crises soon. One is environmental pollution due to the combustion of fossil fuels, and the other is the increasing acceleration towards the depletion of these resources. The main reason for these problems is the significant contribution of fossil fuels to the composition of the energy basket. Fossil fuels currently account for more than $80 \%$ of the world's energy supply [1].

According to British Petroleum Company (BP) Energy Outlook in 2018, renewable energy will be the fastest-growing energy, increasing fivefold by 2040, thus providing about $14 \%$ of global primary energy in this future [2].

At the same time, large oil companies, as a declining industry, are gradually facing potential prospects [3].

As a strategic response to the potential for growth in the renewable energy sector and the increasing cost of hydrocarbon extraction, oil companies are increasingly active in the electricity and renewable energy sectors [4]. Large oil companies are leading the way in developing new strategies to capture part of the fast-growing renewable markets, and while no doubt still struggling with the value of renewables, they can accurately counteract renewable energy in the face of oil developments. Moreover, evaluate the exact gas and time. Since this transfer, they have already made the first choices of capital allocation [5].

Given that global warming, climate change, and widespread droughts are the most important threats to human life, the development of renewable energy combined with the 
rational use of fossil fuels seems to be a good solution. The main indicator for successful development and use of renewable energy is the possibility of competing with other forms of energy in terms of price and cost. This is especially important in developing countries, which have more limited financial resources than developed countries, and, therefore, the optimal allocation of financial resources is essential.

Annual investments in renewable energy have quadrupled to $\$ 12$ billion [6]. From 2009 to 2013, the growth rate of pleasant energy production has increased sixfold, reaching 16 GW. In wind energy, growth has been $250 \%$ and has reached $121 \mathrm{GW}$ capacity. In total, renewable energy has grown by $75 \%$ to $1140 \mathrm{GW}$. The United States is a pioneer in investing in renewable energy with $\$ 24$ billion, and $\$ 2$ billion in renewable energy has been invested in developing countries over a four-year period by 2013 [7]. To date, 73 countries have used renewable energy sources, 64 countries have reached a general policy for the use of renewable energy, and 45 countries have achieved an application for the use of renewable energy [8].

There has been significant global growth in recent renewable energy capacity, mainly since late 2004, when it grew at an annual rate of 10 to 60 percent for many technologies [9]. In fact, by the end of 2015, renewable energy support policies had been implemented in more than 146 countries [10]. The GCC countries have set each of the targets for the deployment of renewable energy at the national or local level [11]. To date, however, the deployment of renewable energy in the GCC has been minimal [12]. Therefore, the stated goals should be supported by defined policies and regulations that reflect the regional context and, therefore, have the highest probability of achieving long-term goals [13]. The policy framework for low-cost renewable energy, especially at the utility-scale, is being sold [14]. The global average energy basket for the year 2015, the initial energy of the world, and the amount of investment for new energies in the world during 2011 to 2020 are shown in Figures 1-3.

Ghouchani et al. [15] used cause and effect relationships to consider effects between barriers, identified barriers and solutions to improve the use of renewable energy in Iran. They analyzed the future trend of renewable energy in Iran to declare investment opportunities and examined three scenarios for analyzing renewable energy in Iran. Solaymani [16] examined trends in energy demand, policies, and development of renewable energies and the causal relationship between renewable and non-renewable energies and economic growth using two methodologies. His results showed that renewable energy technologies currently do not have a significant and adequate role in the energy supply of Iran and also showed that there was a unidirectional causal relationship between economic growth to renewable and non-renewable energy use.

Afsharzadeh et al. [17], in a review paper, answered three questions: why is renewable energy important for Iran at national and rural levels, how is renewable energy related to sustainable rural development, and what are the challenges in the promotion of renewable energy technologies in Iran. They concluded that although renewable energy had the potential for development in Iran's rural areas due to environmental, social, and economic advantages, it could face some infrastructural, managerial, socio-cultural, and economic challenges. In another research, Fadai et al. [18] reviewed the potentials of "renewable energies" (RE) in Iran and its current situation of RE related industries with an emphasis on achieving defined goals and objectives for the fourth national development plan, and also discussed the barriers and causes of non-achievement of these objectives.

As can be concluded from the literature review regarding the policies related to the penetration of renewable energies in Iran's energy supply system, the aforementioned should be considered in the form of reasonable scenarios. On the other hand, in all of the previous studies, there was no integrated policy to overcome the high uncertainties in Iran's renewable energy supply systems. Therefore, it would be much more difficult to design appropriate scenarios for utilizing renewable energy sources than for conventional fossil fuels. Investigating, recognizing, and managing uncertainties using scenario design is, therefore, an essential prerequisite for creating a long-term plan and future insights. In 
this study, we have tried to illustrate the alternative futures of this sector and to determine sustainable strategies for managing renewable energies in Iran using hypothetical planning.

It should be noted that the source of hydropower plants has long been used in Iran due to its many advantages and extremely high efficiency [18]. In Iran, in 2020, fossil electricity accounted for more than $86 \%$ of the electricity supply basket, while the share of renewable energy in this year was low [19]. Iran, in terms of not using its capacity in the ranking, is the first in the world. The question that arises here is why the share of renewable energy in Iran's energy supply portfolio is low. The answer to this question requires identifying and examining factors such as issues related to technology, economics, and marketing. Therefore, in the present project, we first dealt with the technology and general principles related to different types of renewable energy, their position in the world and Iran were described, and then we examined the criteria and macro policies to determine their prioritization and necessity to use them.

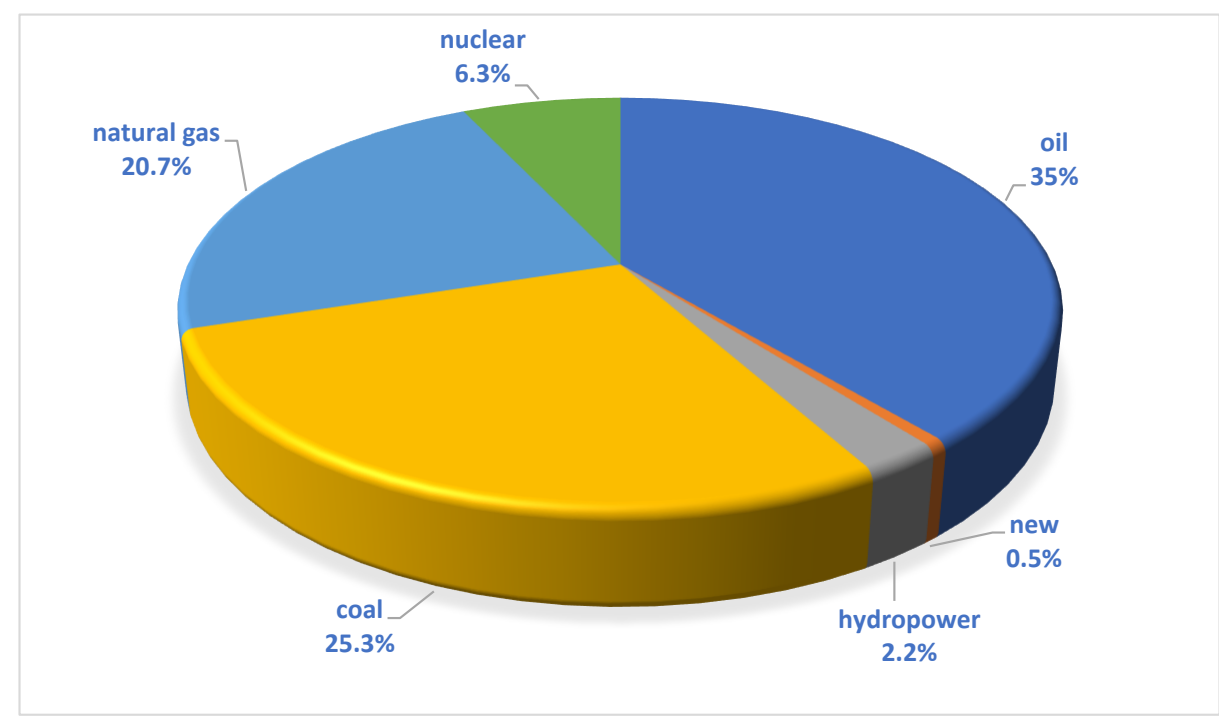

Figure 1. Global average energy basket 2015 [20].

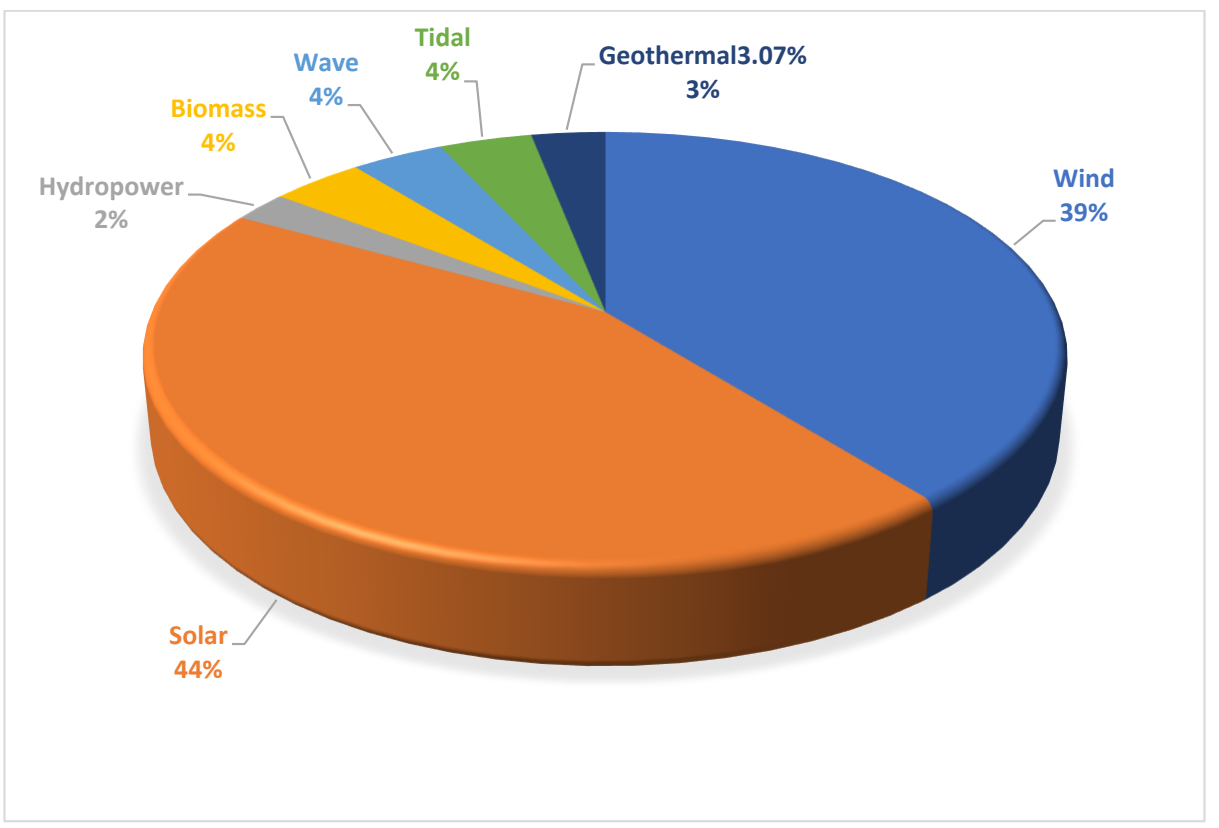

Figure 2. Initial renewable energies in the world [21]. 


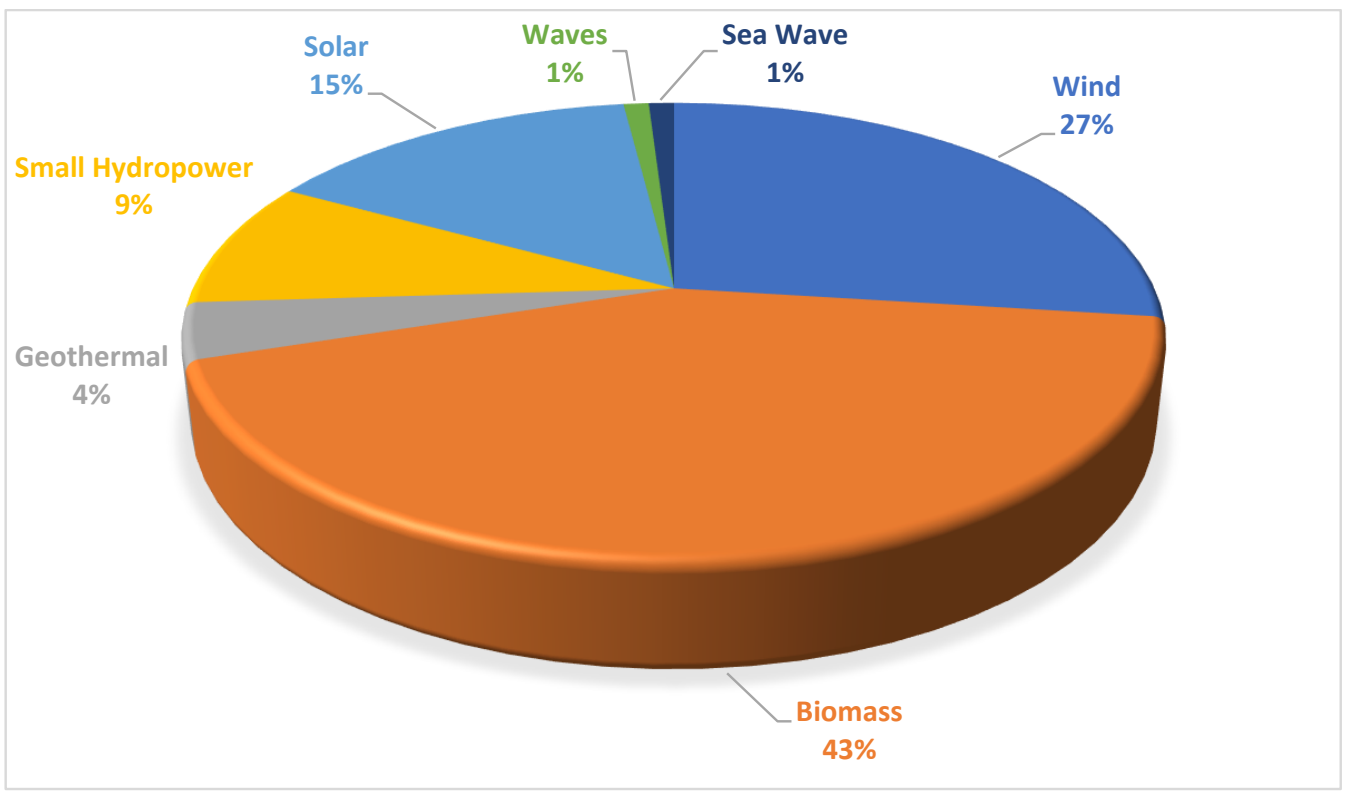

Figure 3. The amount of investment for new energy in the world during 2011 to 2020 [22].

\section{Renewable Energies}

\subsection{Solar}

The sun is a nuclear fusion reactor that works by fusion of hydrogen atoms and continuously emits large amounts of energy into the solar system. Compared to other energy sources, solar energy is one of the most important, accessible, and cleanest sources on the planet. The amount of solar energy that reaches the earth's surface varies greatly during the day and year due to changes in atmospheric conditions and the position of the sun [23]. These changes are spatial (change of geographical location), temporal (hourly and daily), and spectral (for different wavelengths). As sunlight passes through the atmosphere, some of it is absorbed by air molecules, water vapor, aerosols, clouds, and other atmospheric particles, and some are scattered. For example, for a given area, the amount of sunlight decreases with increasing cloud cover.

Solar systems are mainly divided into two categories. The first category is related to the use of solar thermal energy for domestic, industrial, and power plants, which is generated using a solar source through a thermodynamic-heat cycle, and the second category is the direct conversion of light from the sun into electricity by equipment, called photovoltaics. Photovoltaic systems consist of several solar panels that absorb sunlight and convert it directly into electricity. The electricity generated by these panels is a direct type and is converted to alternating current for general use. The most important and expensive part of these systems is solar panels. How to install and direction of installation of these panels plays a key role in the amount of energy received from the sun and consequently increases the production of the system [24].

Solar power plants, especially solar chimneys with hot air, unlike traditional thermal power plants, which need a lot of water during operation, do not need water and, therefore, are very important for arid regions such as Iran. No other environmental benefits, the ability to install and operate in areas far from the grid such as forests and parks, the ability to inject into the national grid without the need for accessories such as substations and transformers, depreciation, and longevity are other benefits of using solar energy. Low energy intensity, access only during the day, irregular clouds and weather, high capital cost, high cost for transportation of electricity or heat from solar energy, and the cost of analyzing the appropriate building location in comparison with the energy value are among the disadvantages of using this type of energy.

In relation to solar dish sterling technology, in these systems, the sunlight is first reflected by parabolic dishes at the focal point. In this way, a high temperature of about 
$1000^{\circ} \mathrm{C}$ is created at this point. Through the installation of a receiver and collector, this high heat is absorbed and transferred directly and indirectly to the Stirling engine and gives the process of generating electricity. At present, due to the low market capacity, this technology is not fully commercialized and has not reached mass production. The distribution of solar power plants built in the world is shown in Figure 4.

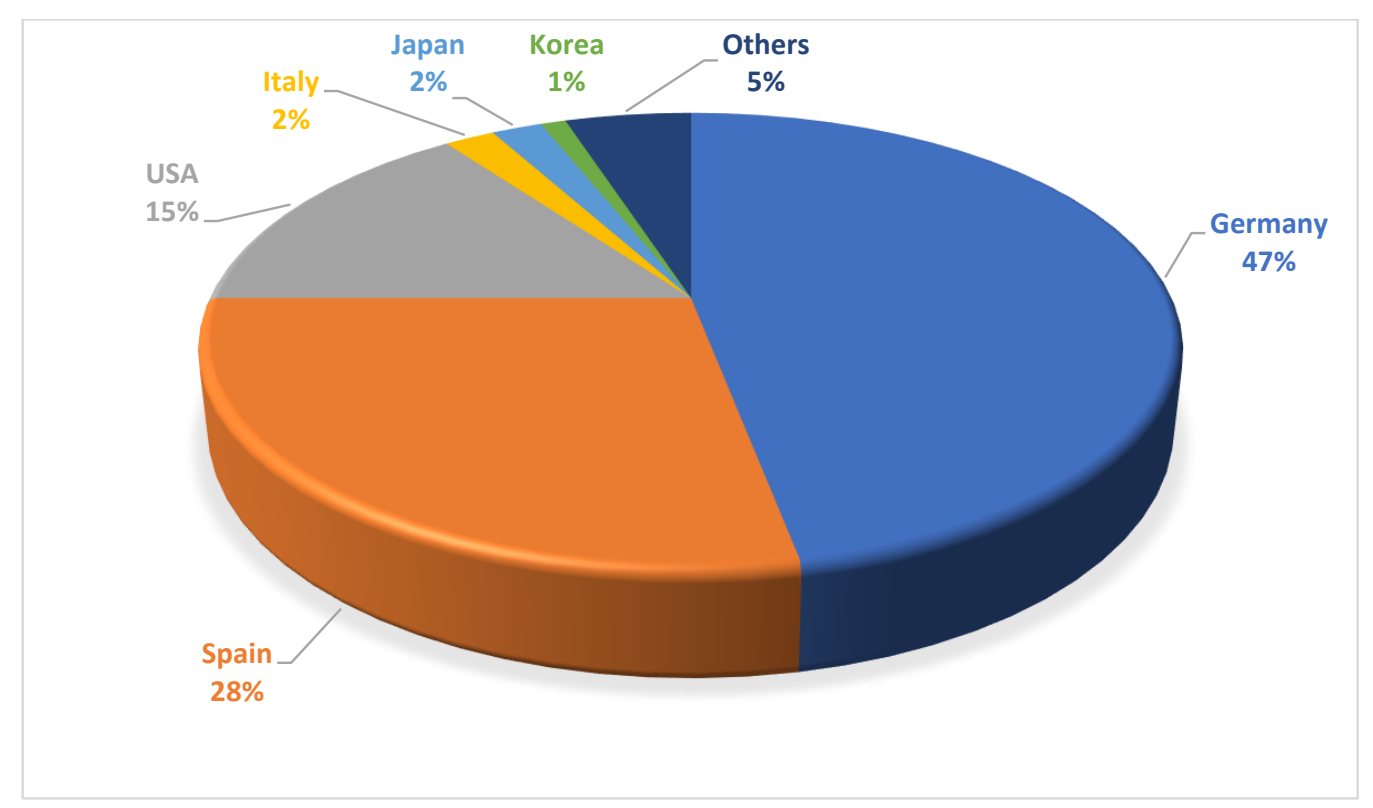

Figure 4. Distribution of solar power plants built in the world in 2017 [25].

The world's solar power generation capacity reached 7800 MW in 2017, up from 3400 MW in 2007. Germany, Spain, the United States, Japan, and Italy ranked first to fifth in solar power usage [25].

\subsection{Wind}

Many years ago, the traditional function of wind energy was in windmills, which were used to move mechanical devices to grind grain or pump water. However, wind power is now being used on large-scale wind farms to power the national grid [26]. Technical use of wind energy is possible when the average wind speed is in the range of 5 to $25 \mathrm{~m}$ per second, and, therefore, most of the wind energy sources are in coastal and mountainous areas. Of course, there are significant resources in the plains [27]. The global estimate of this energy shows that the maximum technical potential that can be extracted from wind energy is about twice the current electricity production in the world. Applications of this type of energy include network connection applications (single wind turbines and wind farms) and disconnected applications from the grid (battery charging and water heating).

The advantages of using this energy include not needing wind turbines for fuel, supplying part of electricity energy demands, diversifying energy sources and creating a stable energy system, high maneuverability in operation (from several watts to several megawatts), and ability to operate at any capacity [28]. In addition, wind energy is abundant, inexhaustible, extensive and clean, and modulates the greenhouse effect. Limitations and disadvantages include the lack of accurate information from wind sources in the region, the impact of weather conditions, and its effects on the environment, such as interference with the landscape and beauty, sound, bird death, and noise in the system. One way to prevent this is to build a set of wind turbines at coastal bases. In addition, there is often twice as much wind on land. Today, the height of wind towers reaches $70 \mathrm{~m}$, thus that it can generate 1.5 megawatts of electricity. However, installing more powerful rotors in these facilities can significantly reduce the cost of electricity from this non-regulated source [29]. 
In 2017, wind power generation was about 14 billion $\mathrm{kWh}$, and the governments have begun implementing policies to support the private sector in this field [30]. Germany, the United States, Denmark, Spain, and India account for about 80 percent of the world's total installed wind energy capacity [31]. The wind power situation of the top 10 countries and the share of installed wind capacity in the world in 2016 are shown in Figures 5 and 6.

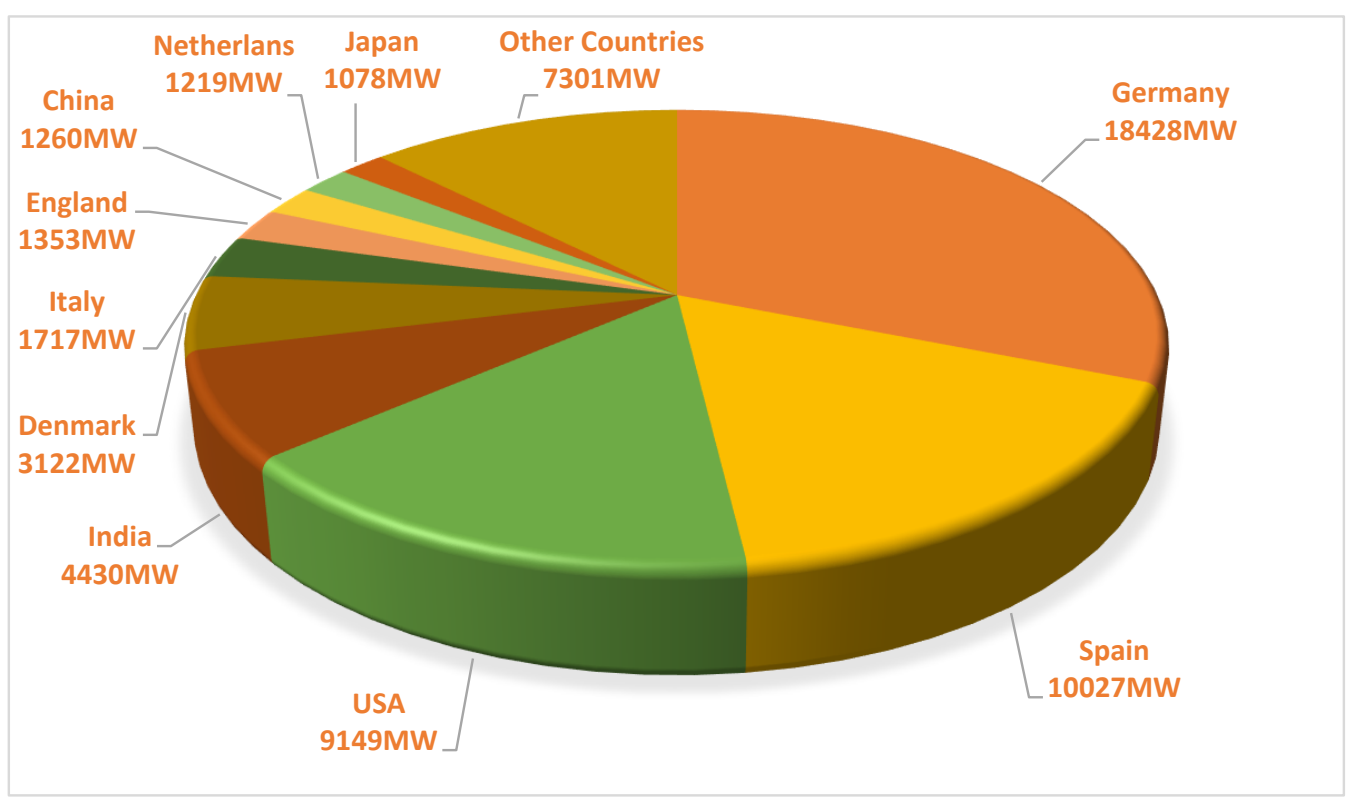

Figure 5. Wind power situation of the top countries [31].

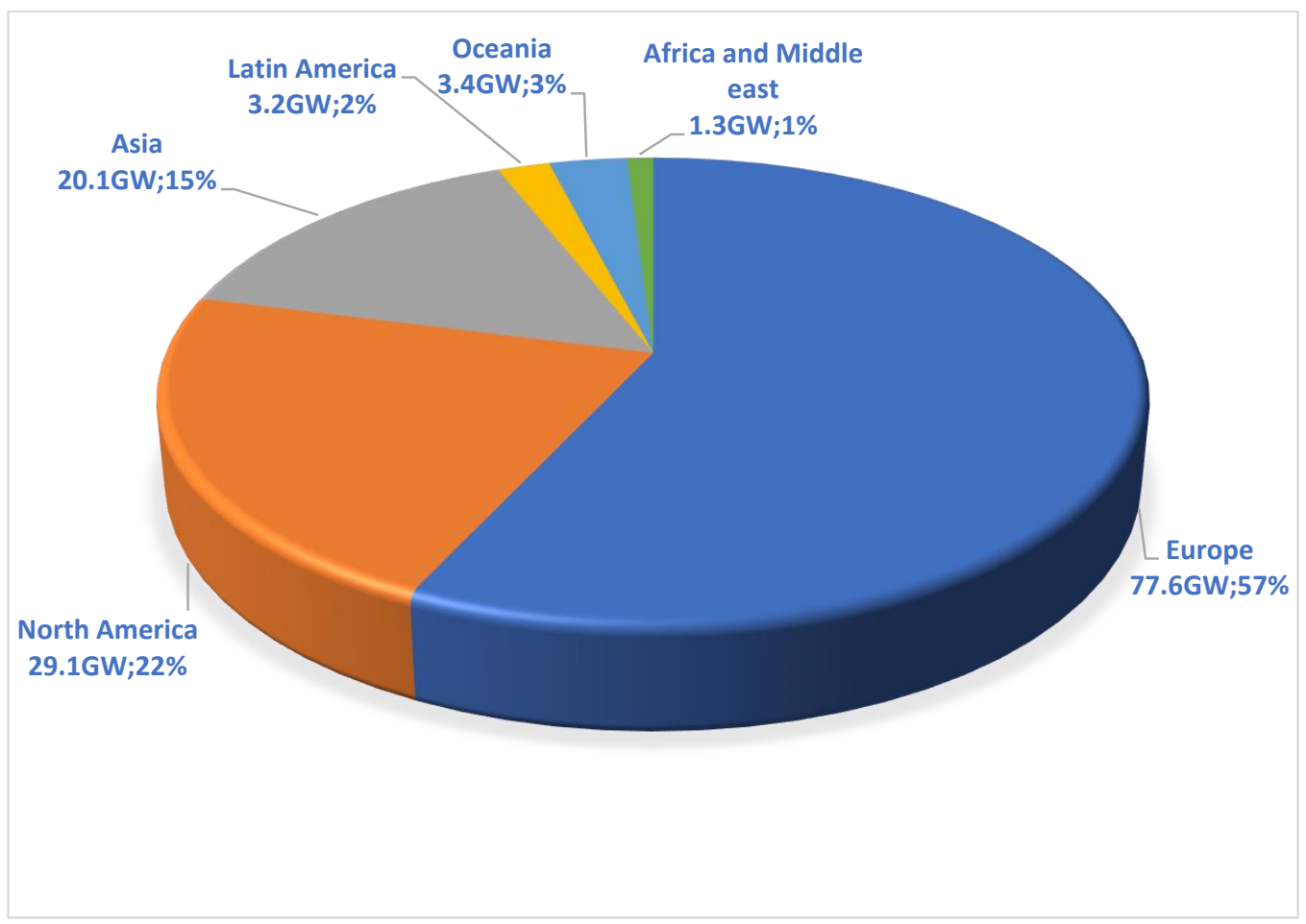

Figure 6. Share of installed wind capacity in the world in 2020 [32]. 


\subsection{Geothermal}

The potential stored in the earth's crust is a huge source of thermal energy, of which volcanic eruptions and hot springs are manifestations. Geothermal energy is usually divided into four categories: hydrothermal, pressurized layers, hot and dry boulders, and volcanic lava. Although their physical characteristics are different from each other, regardless of their economics, each has the potential to generate electricity. Hot water or natural vapors are directed to the surface from drilled wells and used to spin the turbine to generate electricity from geothermal energy. In geothermal power plants, hot water or steam generates electricity by circulating special turbines and related generators. Unlike fossil fuel power plants, no fuel is used in geothermal power plants. This energy can be used in two ways. The first method is a power plant or indirect, and the second method is called a non-power plant or direct. Various methods have been used in the world for electricity from geothermal energy, including dry steam power plant, two-stage instantaneous hot water vapor evaporation power plant, two-cycle rotary turbine system, and combined cycle power plant [33].

Geothermal energy can be extracted and used $24 \mathrm{~h}$ a day, every 365 days of the year, and is also independent of weather conditions. This energy can be used to generate other secondary energy such as electricity without using any fuels such as oil, gas, or coal, which is the reason why geothermal energy is non-polluting. The use of geothermal energy is effective in reducing the emissions of $2 \mathrm{CO}_{2}$ due to the burning of fossil fuels. The first years of operation of this type of energy caused many environmental problems due to the direct release of steam and atmosphere and the flow of hot water into rivers. However, now, with the advent of new re-injection techniques, this problem has largely disappeared and, in many cases, has completely disappeared. On the other hand, due to the fact that geothermal energy sources are often located in the heart of nature or in remote areas, in terms of choosing the location and type of design and size of power plants should be very careful [34].

Currently, more than 20 countries in the world use this huge source of energy to generate electricity by installing geothermal power plants, which have a total installed capacity of $8400 \mathrm{MW}$ [35]. Japan, New Zealand, and Iceland rank first to eighth in the world in the use of this energy.

\subsection{Hydropower}

Restrictions on fossil fuels and environmental issues have led countries around the world to use clean energy instead of polluting energy to supply energy in the future [36]. The growing trend of marine technologies has led to more attention being paid to the very valuable role of seas and oceans in producing energy. Seas receive and store energy through various physical processes and then waste it. This energy is available in the form of waves, tides, temperature differences, and salt concentration differences at different depths of seawater, each of which can be exploited. The energy of sea waves is the mechanical energy transmitted by the wind, which is stored in waves for a short period of time as potential and kinetic energy. Another type of energy that is stored as long-wavelengths due to the rotational motion of the earth and the gravity of the moon and sun is discussed as tidal energy. The energy stored in warm surface water, which can be used due to the deep and cold waters of the oceans, is discussed as the thermal energy of the sea. Despite their diversity, these energies have common features. Research in this area is expanding rapidly. The tidal energy of the oceans as one of the renewable resources has the highest level of access among these resources. In Corera's article, environmental issues and the potential of tidal energy sources in the world as well as our country Iran have been studied. Countries in the world and places in Iran in the field of tidal power have been introduced where after practical experiments and modeling of a power plant, a tidal power plant can be built there [37]. 
There are currently 800 gigawatts of hydroelectric power plants installed in the world, with Norway ranking first in the use of these power plants [38]. Tajikistan, Kyrgyzstan, and Brazil are next in line.

\subsection{Biomass}

One of the most suitable sources of renewable energy is biomass energy or biomass. Abundant sources of biomass in nature include plant resources and agricultural wastes, municipal waste and sewage, food industry, and animal waste. Of course, biomass energy sources can meet the needs of different sectors of human society in the main form of energy such as electricity or energy carriers such as gaseous and liquid fuels, which is the difference between biomass energy and other renewable energies. The range of biomass consumers is very wide. For example, it starts from small households, especially in rural areas and restaurants, and continues to small, medium, and large industrial and commercial units. Since biomass resources due to anaerobic and biochemical activities mainly produce methane gas, the systems that can be used to produce energy from these different sources will be different. For example, methane gas can be extracted from municipal waste in a landfill, or energy can be generated using incinerators [39].

The advantages of this type of energy include the abundance of biomass resources and availability throughout the country, the high potential of energy production from biomass resources compared to other new energies, the ability to generate electricity (on a large scale power plant), and heat using the mentioned municipal waste and sewage and the reduction of adverse environmental effects as a result of the use of biomass resources in the process of energy conversion (electric or thermal). Of course, bioenergy processes can cause a lot of pollution because these processes will have products that, if left in nature, in addition to causing health problems, will cause greenhouse gas emissions and environmental degradation. Replacing natural forests, whether tropical or temperate, with single-product afforestation schemes that may jeopardize biodiversity. Swamps and wildlife habitats may also be threatened, and the disappearance of areas of stunning natural beauty and ecologically sensitive areas is one of the disadvantages of this type of energy [8].

Sweden is one of the best consumers of biogas in the transport industry, and it is planned that by 2050, 40\% of the country's needs in the transport sector will be met through biogas. In addition, in Western European countries, Southeast Asia, and especially China and India, this technology is very significant, and these countries have used this technology to meet their fuel needs [40].

In general, it can be used for biomass power plants in the forms of biogas, synthesis gas, biodiesel, and biohydrogen.

\subsection{Hydrogen and Fuel Cell Technologies}

Given the nature of most new and renewable energies that need to be accessed at the right time and place to store and transport them, the use of hydrogen as an energy carrier is a necessity. Hydrogen is now being named as the future fuel of humankind. It is possible to produce hydrogen from clean and fossil energy sources, and by producing hydrogen from new and renewable energy sources, it is possible to store the energy of the above-mentioned sources and use it at the right time and place. The direct combustion of hydrogen in internal combustion engines or the chemical reaction in the fuel cell and the generation of electricity without pollution is the advantages of hydrogen as a clean energy carrier. However, the main advantage of using hydrogen as a fuel is that after the combustion of the product, steam, water, and nitrogen oxides are produced. Another advantage of using hydrogen is that it can be easily transported and moved through a pipe. The amount of heat generated by combustion per unit weight is higher than any other fuel used, and the remainder in a closed environment can be quickly removed by airflow, which is also less than other toxic fuels.

Installation and operation of a $2.5 \mathrm{MW}$ polymeric Fuel Cell and also Designing and Manufacturing $500 \mathrm{~kg}$ Polymeric Fuel Cell with the aim of achieving technical knowledge 
are some of the most important projects carried out in the field of fuel cells in the world in recent years [41].

\section{Strategic Policies for Renewable Energy}

Energy policy in recent years has become particularly important in terms of increasing the role of energy and the environment in the economic, political, and social activities of different societies [42]. However, in the past, after the oil shock of 1973, in which the Arab countries producing crude oil closed the oil valves on the Western world, there has always been concern about the recurrence of such a situation in developed countries and in recent years in developing countries such as China and India have existed. Ensuring a secure and sustainable supply of energy as well as a demanding market with proper traction and growth is one of the main concerns of any country for its comprehensive development.

This would not be possible without energy policy at the level of industrial enterprises, local councils and municipalities, national governments, and the international level. A set of purposeful actions pursued by an actor or a group of actors in the face of a particular problem or issue is called policymaking [43]. Energy policy is a framework of written and unwritten rules and practices that are generally developed over decades. In this context, mainly all levels of government in a country, as well as the private sector, are involved. The effects of economic, social, and political aspects of society, which are not necessarily related to energy at first glance, are discussed in interaction with energy. Energy policy seeks to improve the ways in which energy resources are produced or consumed [44].

Thus far, energy has been viewed only from an engineering perspective and sometimes from an economic and technological perspective. Moreover, in the process, concepts such as optimization, efficiency, balance have been more important, and decision-making has been based on this. Recent advances in political science, social psychology, sociology, development economics, and environmental economics have given new energy to policymaking. In energy policy, a dynamic approach is considered instead of a static approach because policy variables are changing rapidly [45].

As mentioned earlier, in recent years, due to the depletion of non-renewable energy sources, global warming, and environmental issues, the emphasis on renewable energy has increased. Given this global trend and the issues raised about the importance of renewable energy, there is a need to develop a strategy in this area. Government policies for the development of renewable energy can be divided into direct and indirect policies. Supportive policies for this type of energy, such as raising purchase tariffs, reducing taxes, and financing the construction of a renewable power plant, are among the direct policies of the government. Indirect policies are policies that increase the competitiveness of renewable power plants against fossil fuel power plants.

One of these policies is the liberalization of energy prices (the law on targeted subsidies) or the pricing of fuel delivered to power plants. Implementing energy carrier pricing policies can have a significant impact on the development of renewable energy plants by increasing the cost of electricity for fossil power plants. In addition to the economic parameters and the cost price of electricity generated, numerous other parameters are considered in policy-making decisions to prioritize and evaluate the justifiability of electricity with renewable energy, along with other options for electricity generation in a country.

Therefore, the need to form a robust strategy to fit these parameters is strongly felt. Due to the common concerns to respond to this need among different countries, the decision-making method of the two countries was studied in order to answer the basic questions raised in this field with the help of a comparative study and obtain a general strategy and policy. The purpose of some comparative studies is simply to describe two or more phenomena or situations by comparing their characteristics, while other comparative studies have purposes beyond description and involve judgment and evaluation and can include all types of comparative research, comparative studies, and classification studies. Include national and transnational levels. 
For example, despite the huge fossil resources in Iran, is it reasonable to invest in the development of new energy in the current situation? If the answer is positive, what are the perspective of these energies and their share in the country's energy basket? What are Iran's technological priorities in the field of renewable energy, and what strategies should Iran adopt to develop these energies? To find the methodology for answering these questions, two sample countries from West Asia and Eastern Europe were selected. The reason for this choice was that in countries such as Iran, due to the huge resources of fossil fuels, the pace of movement towards renewable energy is not high.

In these two countries, issues such as the transparency and applicability of the methodology, the level of access to the fossil reserves of those countries, the importance of the environment for the people, the economic growth of the countries and GDP per capita are considered, which are very close to the criteria inside Iran. A common point in the study of both countries was the use of scenario planning method, which is due to the "importance of energy" and "uncertainty" about the future of energy. An overview of these scenarios in different countries, before examining the potentials and feasibility of resources within Iran, which will be explained in the following sections, gives a broad view of how a country policy to develop renewable energy, and finally makes conclusions and decisions easier for Iran.

First, the scenarios facing Saudi Arabia are presented and discussed (see reference [46]) and are shown in Figure 7. In this strategy, experts from both industry and academia with orientations in economics, environment, medicine, and politics were selected to participate in the survey, who identified three driving forces in this field. The scenarios were developed under these three drivers, a diagram of which can be seen in Figure 7. The impulses obtained included access to fossil fuels, environmental responses, public awareness, and understanding of new energies. Expert opinions were obtained to identify the drivers in three steps.

In the first stage, general questions were asked about Saudi Arabia's need for renewable energy and the role of this energy in the future. In the second stage, the answers were given feedback, and this time the experts were asked for more reasons for their opinions. In the third step, the final answer was obtained, and the drivers were identified. In addition, a preliminary design of the scenarios was prepared with the help of experts and finalized. After developing the scenarios, items such as the amount of fuel storage, the amount of land required, cost savings and its rate of return, as well as the potential of greenhouse gases in the space of each scenario, were compared with each other. The results of this comparison were made available to the decision-makers thus that they could choose the appropriate scenario or implement a combination of four scenarios according to the circumstances. The choice or non-choice of scenarios is based on the decision of policymakers. Figure 8 shows the trajectory of this study.

The next country to study was Russia. The general guide to Russia's energy movement is its energy strategies until 2020 and 2030 [47].

By studying these strategies, Russia does not have a serious determination to expand renewable energy in the next ten years. In this country, energy planning is conducted regionally. Scenarios facing Saudi Arabia are shown in Table 1. 


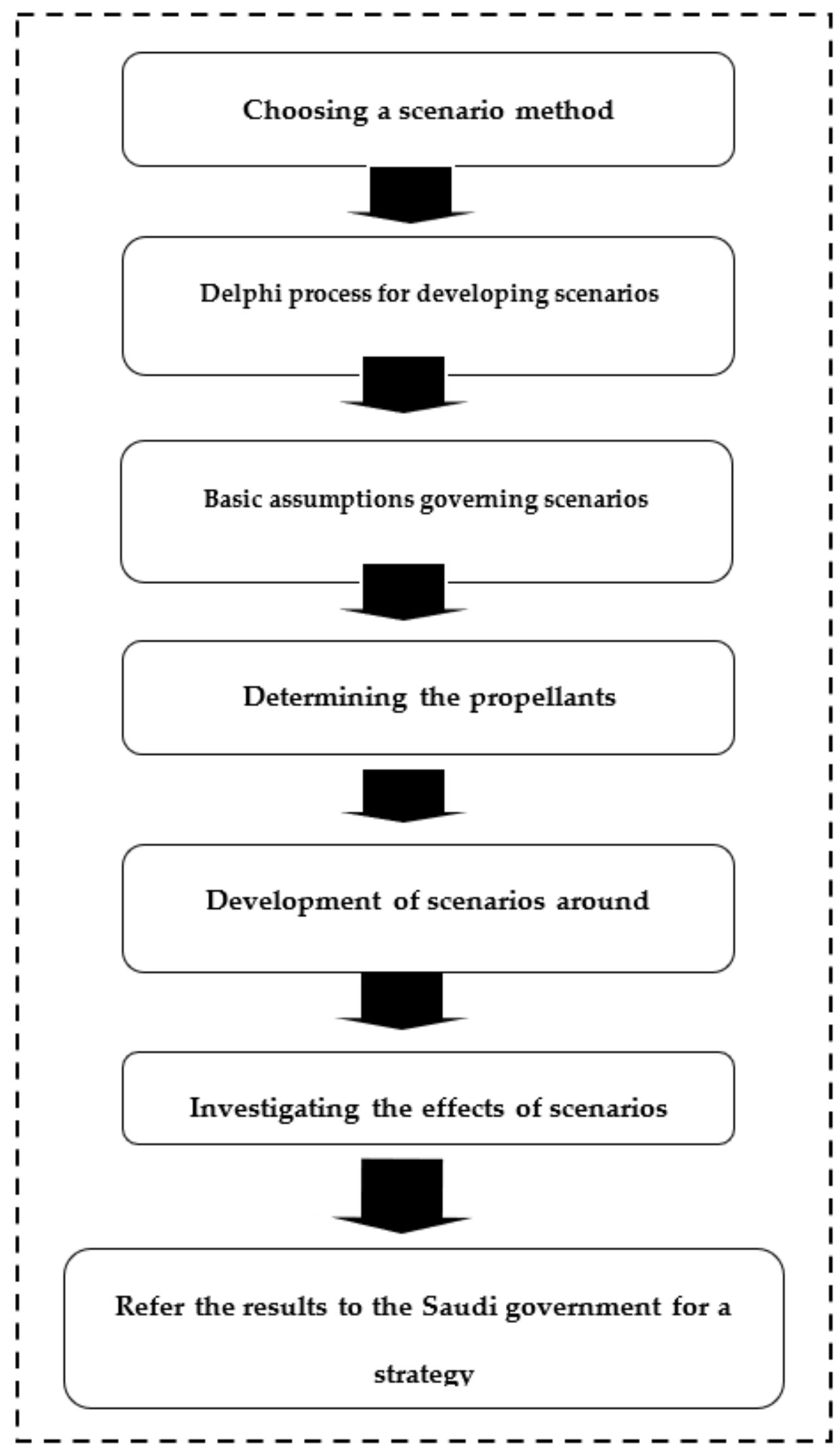

Figure 7. Scenario development process in Saudi Arabia [46]. 


\section{High GDP growth and real international cooperation}

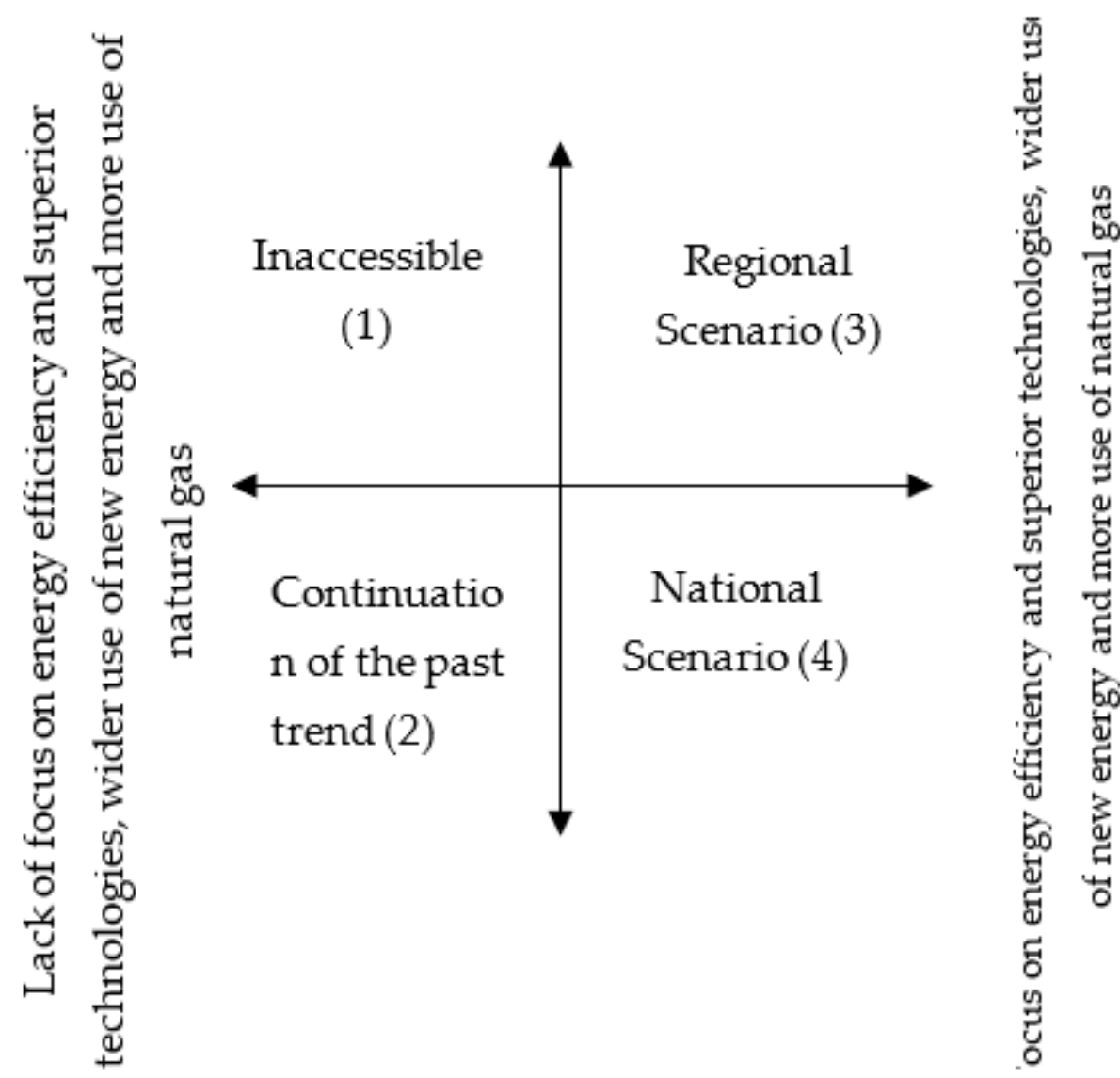

\section{Average growth of GDP and lack of real international cooper}

Figure 8. Logic scenario development in Russia [47].

Table 1. Scenarios facing Saudi Arabia. $\mathrm{P}$ is the positive view of people, and $\mathrm{N}$ is the negative view of people about renewable energies. L and $\mathrm{H}$ indicate "low" and "high" [46].

\begin{tabular}{|c|c|c|c|c|c|}
\hline Scenario Number & $\begin{array}{c}\text { Access to Fossil } \\
\text { Fuels }\end{array}$ & $\begin{array}{l}\text { Action for the } \\
\text { Protection of the } \\
\text { Environment }\end{array}$ & $\begin{array}{c}\text { People's View of } \\
\text { Renewable } \\
\text { Energy }\end{array}$ & $\begin{array}{c}\text { Value of } \\
\text { Productions }\end{array}$ & Technologies \\
\hline 1 & $\mathrm{H}$ & $\mathrm{L}$ & $\mathrm{P}$ & $15 \%$ & \multirow{2}{*}{ Solar PV } \\
\hline 2 & $\mathrm{H}$ & $\mathrm{L}$ & $\mathrm{N}$ & $10 \%$ & \\
\hline 3 & $\mathrm{H}$ & $\mathrm{H}$ & $\mathrm{P}$ & $15 \%$ & \multirow{2}{*}{ Solar Thermal } \\
\hline 4 & $\mathrm{H}$ & $\mathrm{H}$ & $\mathrm{N}$ & $10 \%$ & \\
\hline 5 & $\mathrm{~L}$ & $\mathrm{~L}$ & $\mathrm{P}$ & $15 \%$ & \multirow{2}{*}{ Wind power } \\
\hline 6 & $\mathrm{~L}$ & $\mathrm{~L}$ & $\mathrm{~N}$ & $10 \%$ & \\
\hline 7 & $\mathrm{~L}$ & $\mathrm{H}$ & $\mathrm{P}$ & $45 \%$ & Solar PV, Solar \\
\hline 8 & $\mathrm{~L}$ & $\mathrm{H}$ & $\mathrm{N}$ & $30 \%$ & Thermal and Wind \\
\hline
\end{tabular}


The areas are grouped under the Russian Ministry of Energy, and the general direction of Iran's movement is presented in a report entitled "Energy Strategy." One of these regions is the Far East of Russia, which includes nine provinces. With the help of experts, 70 drivers were identified for the development of scenarios, which were divided into 11 groups. These 11 groups were the structure of the energy industry market in the Far East of Russia, decisionmaking and inclining the public and private sectors to renewable energy, coordination between different actors in this field, regional and national political factors, external energy market conditions, internal energy relationship. Moreover, the national economy and social development, national and regional priorities, and actions include energy policies, economic development, infrastructure and investment, technology development, and the state of natural resources. Then, these 11 groups were placed in two axes.

The vertical axis was "GDP growth and real international cooperation" which was designed in two directions. The horizontal axis was named "Focus on energy efficiency and superior technologies, wider use of new energy and use of natural gas." This axis is also gathered in the Ministry of Energy, and the general direction of the country's movement is prepared in a report entitled "Energy Strategy" and is approved by the President. One of these regions is the Far East of Russia, which includes nine provinces. With the help of experts, 70 drivers were identified for the development of scenarios, which were divided into 11 groups. These 11 groups are the structure of the energy industry market in the Far East of Russia, decision-making and inclining the public and private sectors to renewable energy, coordination between different actors in this field, regional, and national political factors, external energy market conditions, internal energy relationship.

And the national economy and social development, national and regional priorities and actions include energy policies, economic development, infrastructure and investment, technology development, and the state of natural resources. Then, these 11 groups were placed in two axes. The vertical axis was "GDP growth and real international cooperation" which was designed in two directions. The horizontal axis was named "Focus on energy efficiency and superior technologies, wider use of new energy and use of natural gas." This axis was also designed in two directions of decentralization and concentration. Based on these two drivers, four scenarios were designed, which can be seen in Figure 8. As can be seen from this diagram, the regional scenario is a suitable space for the development of renewable energies. In the national scenario, the movement takes place at a slower pace than the regional scenario, and as the past trend continues, there will be no significant development in the use of these energies. It is impossible not to focus on the expansion and development of renewable energy if there is a high growth of GDP. In the space of each scenario, the cases of energy demand and its increasing trend, from 2002 to 2030, the structure of energy demand (oil, hydro, gas), greenhouse gas emissions, and the cost of implementing each scenario were compared.

The result of this comparison is sent to the Ministry of Energy thus that decisionmakers can choose the appropriate scenario based on these results. The general process of work can be seen in Figure 9.

It is worth mentioning that the study of the structure of the renewable energy management system in these two countries is only for the purpose of obtaining new ideas and applying them in the process of designing the optimal structure of renewable energy in the country. Looking at the development of renewable energy in the two countries and considering the short history of activity in this field, an acceptable record should be attributed to the efforts of these countries. Comprehensive strategic plans for medium- and long-term goals have been formulated and implemented in these countries, and, therefore, a promising future can be seen in the development of all these clean resources ahead of these countries. However, what emerges from this study is that the level of utilization of these clean sources will be affected by the availability of fossil fuels and their price. On the other hand, these studies show that the continuation of serious political support for renewable energy is also of great importance for achieving the goals of the vision. 


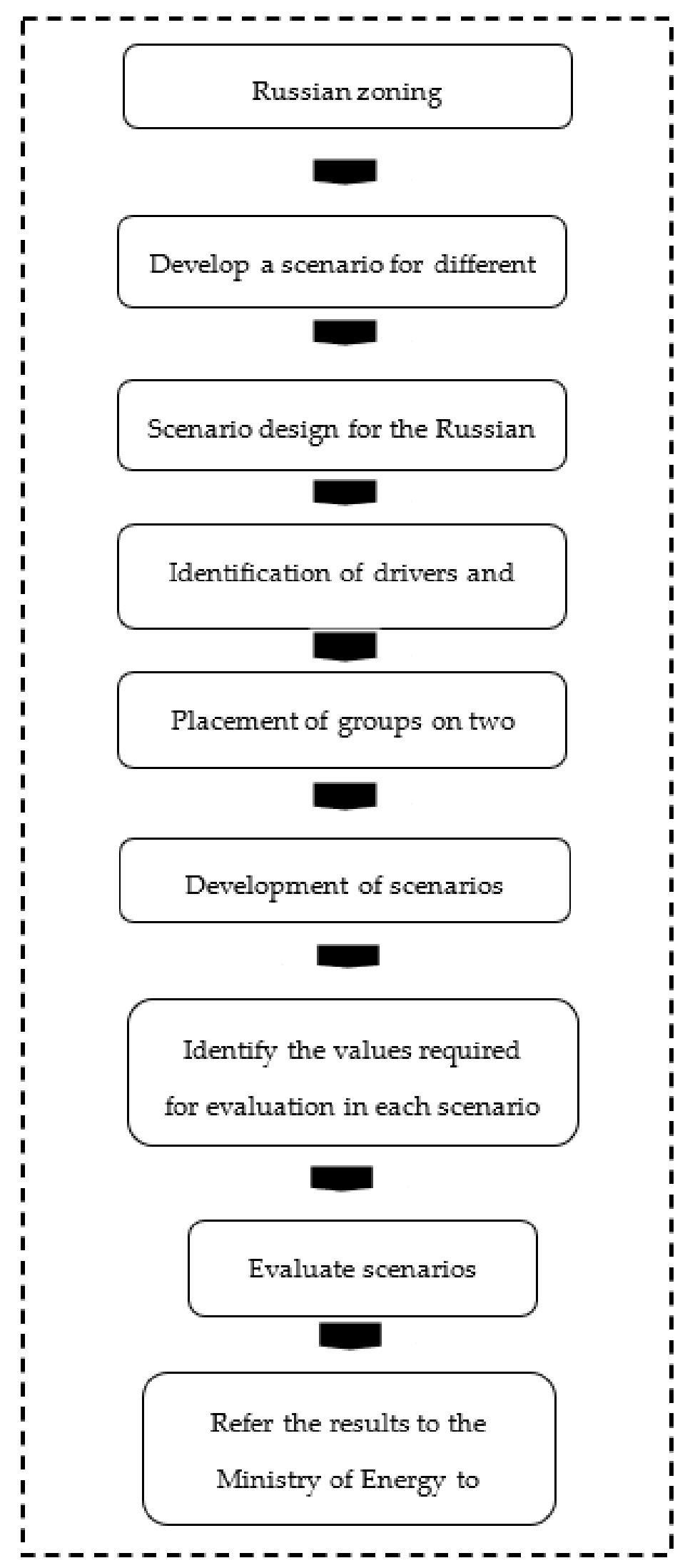

Figure 9. Scenario development process in Russia [47]. 
For many years, with the increase of human knowledge and understanding, the quality and status of life have always been improving and improving. The only Asian country that was partly associated with the economic growth of the nineteenth century and the early twentieth century was Japan. Recently, economic corridors have been concluded between Asian countries. The Sino-Pakistan Economic Corridor, for example, is a series of infrastructure projects currently under construction across Pakistan. Its economic value was initially $\$ 46$ billion but has now reached $\$ 54$ billion. The economic plan aims to rapidly modernize Pakistan's infrastructure and strengthen its economy by building modern transportation networks, generating power plants, and creating special economic zones. With the launch of the China-Pakistan Economic Corridor projects, a lack of comprehensive foresight on future energy use has led to unfavorable economic and social consequences.

Therefore, it is necessary to comprehensively examine future energy demand and its determinants in order to be accompanied by appropriate political decisions in advance [48] Rare information is available on future energy forecasts for the China-Pakistan Economic Corridor for Pakistan as a whole and at the sector level [49]. In the article, Khan et al. collaborated with the country's specific experimental work by estimating future energy consumption and its savings potential by 2030 [50]. Prose et al. made predictions of future energy consumption based on scenario analysis and Monte Carlo simulations [51]. Investment in water, wind, and solar projects reflects the improvement of low carbon development scenarios in Pakistan [52].

Preliminary work on energy saving potential involves estimating the stored energy supply curve. This method is used to assess the relationship between energy costs and potential savings of various conservation technologies [53]. Basic work on the potential of energy saving using this method has been conducted by Fallahi et al. [54]. In contrast, the index breakdown method is not considered a suitable method because it ignores price effects [55]. However, this method has been used to calculate emission reduction potential for economies around the world [56]. Scenario analysis has attracted a lot of attention in recent years in the analysis of energy consumption and its savings potential [57].

Several scenario studies have been conducted to advise policymakers on the future energy system in line with public policy objectives [58]. The scenario approach is a useful tool for presenting alternative results related to various decisions and strategies adopted in economics [59]. Scenario analysis based on econometric models is considered as an appropriate technique in modeling energy demand in both the short and long term and explains past behaviors, future forecasts, and the effects of different policies in a single study make it possible [60]. While dealing with energy demand modeling and forecasting, no single discipline offers a flawless approach. However, joint integration analysis has typically been used to estimate energy demand performance in recent articles [61]. This review of articles also shows that scenario analysis and Monte Carlo simulations have been frequently used in articles to predict energy demand [62].

\section{Background, Potential, and Rationale for Renewable Energy Development}

Iran, a developing country with a population of 80 million, is the second-largest oil producer in OPEC and the second-largest producer of natural gas in the world [19]. Iran is also the first holder of coal reserves in West Asia and North Africa. On the other hand, geographical diversity has enriched the country with significant renewable resources, including solar, wind, geothermal, and hydropower. Thus that the region with the most sunlight in Dina (Shahdad, Kerman province), the highest annual wind distribution in the world (Mirjaveh, Sistan, and Baluchestan province), the most powerful hydrothermal geothermal resources in the world (Meshkinshahr, Ardabil province) and the second-largest water resources, is a region of West Asia (Khuzestan province).

On the other hand, the demand for energy in this country has been growing rapidly. In recent years, environmental concerns and other energy issues have prompted the Iranian government to make efforts to increase energy efficiency and make more use of renewable energy sources. 
In theory, it can be assumed that, given the abundance of oil and gas reserves, Iran is able to delay any effort to develop renewable energy [63]. However, environmental impacts play an important role in policymakers' decisions, and the continuous increase in the use of fossil fuels in Iran has had a detrimental effect on health and the environment. The total environmental damage caused by environmental pollution (mainly including $\mathrm{PM}_{10}, \mathrm{SO}_{\mathrm{x}}$, $\mathrm{NO}_{\mathrm{x}}$, and CO) in 2006 was estimated at $\$ 4.7$ billion or $5.7 \%$ of normal GDP [64].

According to forecasts made in the field of energy, with the continuation of the current trend, in 2029, this amount will reach twice the current level. Iran is one of the 20 greenhouse gas-producing countries that produce a total of $75 \%$ of the world's total greenhouse gases [64]. For other countries, another influential factor in the development of renewable energy is the rising costs and declining access to oil reserves. Currently, the renewable energy development plan is in accordance with Table 2, which is not as much as the projected global values of the country's potential, and this indicates that there are probably obstacles and challenges facing this industry in the country.

Table 2. Development in the field of renewable energy until 2027 [65].

\begin{tabular}{cc}
\hline Capacity (MW) & Technology \\
\hline 1600 & Wind energy \\
130 & Biomass energy \\
100 & Geothermal energy \\
90 & Fuel cell \\
40 & Photovoltaic energy \\
40 & Solar thermal energy \\
2000 & Total \\
\hline
\end{tabular}

\section{Renewable Energy Development Program: Obstacles and Challenges}

There is no doubt that the biggest constraints on the acceptance of renewable energy in Iran are long-term access to fossil fuels and the current energy pricing system, especially the low electricity tariff due to the high subsidies for natural gas.

Under conventional energy prices, there is no incentive for the private sector in Iran to invest in renewable energy, which has a higher production cost than other energy derivatives. Of course, since the last 12 years (2010), the law on targeted subsidies in Iran has reduced this problem to some extent, but it is still not enough. Targeting subsidies in Iran is one of the most important parts and the most visible part of the economic transformation plan. It changes the process of giving subsidies. In this process, with the gradual removal of subsidies from fuel, food, water, electricity, and other items in Iran, the type of giving subsidies changes, some of which have been removed, in the form of cash is paid to the people and the rest of the income is spent on civil and cultural works.

Renewable energy plants have high initial costs that require high investment costs on the part of investors. At the same time, the cost advantage of generating electricity from fossil fuels in the case of Iran may be more pronounced due to the abundance of natural gas. In Iran, another serious economic problem is the consideration of the same price for all types of renewable energy, which may discourage investors from investing in less advanced but promising technologies. Experience in other countries has also shown that the tariff mechanism, in turn, is not a sufficient incentive and will always work better with other financial incentives, especially those that lead to lower initial investment costs. It is clear that existing policy and regulatory frameworks in the field of renewable energy need to be reviewed and updated, which can be adapted from the experience of other countries (see Part 3, Strategic policies for Comparative Study).

\section{Renewable Energy in Iran: Status and Potentials}

Basically, renewable energy technologies in Iran are related to grid-connected power generation technologies [66]. These technologies include offshore wind farms, medium and small hydropower plants, geothermal power, concentrated solar heat power, solar 
photovoltaics, and landfill gas (biomass energy). The following is a closer look at the potentials of various types of renewable energy in the country.

Briefly, more than three billion people live in rural areas of low- and middle-income countries. In most cases, rural households have high needs for energy, including cooking, lighting, heating, transportation, and telecommunications. The main purpose of Karami et al.'s study was to implement a conceptual model using renewable energy in rural areas of Iran [67]. After determining the calculated values based on meteorological station data, IDW interpolation method was used in GIS software for the entire geographical area of the province. After surveying several areas and identifying potential classes, a village with sufficient potential for solar and wind energy (Kahkesh village) was selected, and then a field survey was conducted based on biomass resources. The needs of rural residents and the potential of rural renewable energy were examined by studying conceptual frameworks over a year. By dividing the energy value of the frameworks, the amount of energy savings can be calculated. Iran's energy consumption basket is shown in Figure 10.

\section{Iran Energy Consumption Basket 2015}

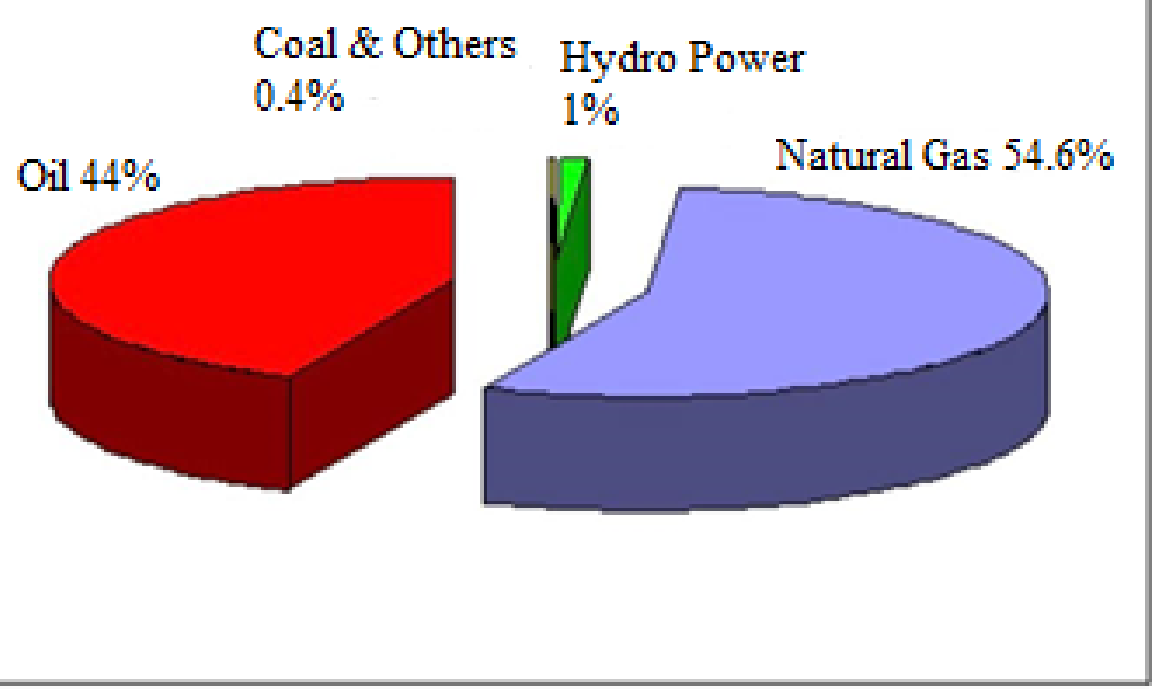

Figure 10. Iran Energy Consumption Basket 2015 [68].

\subsection{Solar}

Sunlight per day in more than two-thirds of the country is about 4.5 to $5.5 \mathrm{kWh} /$ cubic meter. There are currently more than $2900 \mathrm{~h}$, and, in some places, more than $3200 \mathrm{~h}$ of sunshine throughout the year in the country. The number of cloudy days behind the country throughout the country is less than five days a year, and the transparency of air in most parts of Iran is considered more than $60 \%$. It is natural that using solar energy to supply hot water for consumption in our country will be cost-effective [69].

Iran is one of the most talented regions for the construction of concentrated solar power plants in the Middle East, with an average direct radiation average of $5.5 \mathrm{kWh}$ per square meter per day and about 300 bright sunny days per year [70].

As shown in Figure 11, the central and southern regions of Iran, such as the provinces of Yazd, Fars, Isfahan, and Kerman, with average daily direct radiation between 5.5 to $6.5 \mathrm{kWh}$ per square meter per day, have high solar radiation. 


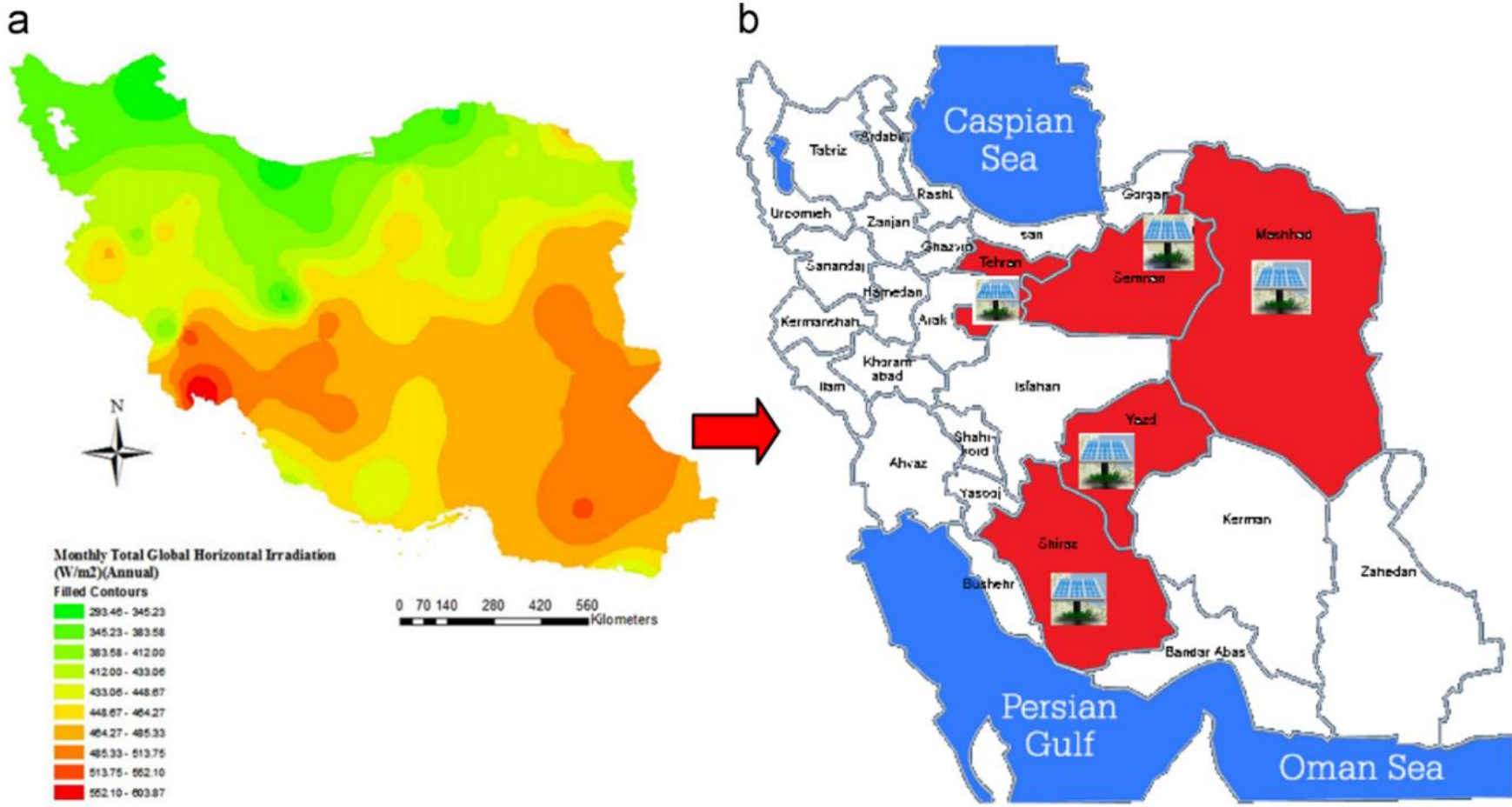

Figure 11. Distribution of medium direct radiation in Iran (a) and an enlarged built solar power plants (b) (Reprinted with permission from ref. [71] copyright 2016 Technical Report).

In addition, according to a study by Marefati et al., Shiraz (the capital of Persia) is the best region in Iran to exploit the solar potential and establish centralized solar power plants [72]. In the study of Hirbodi et al., the performance of centralized solar power plants, including parabolic systems and solar towers in the climatic conditions of southwestern Iran, has been technically and economically analyzed. The dry cooling place for concentrated solar power plants in the south-central regions of Iran has no justification due to its minor effects on technical and economic performance and due to the lack of water in such areas. The wet cooling system increases the annual water consumption by about 14 times but improves the technical and economic performance of the power plants by less than $4 \%$ and $5 \%$, respectively.

Solar tower power plants have an annual power generation and a higher capacity factor and lower power level costs compared to parabolic power plants. Therefore, a 100megawatt dry-cooling solar tower with $14 \mathrm{~h}$ of thermal energy storage and solar multiplier 3 is recommended as the most efficient option for exploiting the solar potential in the south-central regions of Iran [73].

In the study of Shorabeh et al. [74], with the aim of evaluating the technical, economic, and environmental dimensions of parabolic catchment plants and solar towers in the climatic conditions of southwestern Iran with an average of natural direct radiation of about $6 \mathrm{kWh}$ per square meter per day. Based on the results, the optimal settings for the studied power plants are determined in relation to the economic-technical parameters. The 100-megawatt dry-cooled solar power plant, $14 \mathrm{~h}$ storage system, and 3.0 solar multiplier have been found to be among the most efficient settings in the weather conditions under investigation. For this concentrated solar power plant, the cost-balanced cost of electricity and solar-to-electricity efficiency was $11.3 \%$ per kilowatt-hour and $14.7 \%$, respectively. In addition, the energy recovery time is about 15 months, reducing the annual carbon dioxide emissions by 399 kilotons and saving the annual fossil fuel 190 million cubic meters of natural gas [75].

Until today, close to $500 \mathrm{KW}$ of photovoltaic systems have been installed in Iran. More network-independent applications for telecommunication reporting stations, park and 
tunnel lights, intermediate telephones, border police stations and foresters' stations, solar pumps for agricultural purposes, and rural homes in rural villages. The provinces are Yazd and Semnan. The only grid-connected application that has been installed thus far is a KW30 system in the Taleghan area, about $110 \mathrm{~km}$ from Tehran.

However, at present, there is no plan to install and operate a grid-connected photovoltaic system on a practical scale, either to power and amplify the grid, or for peak consumption times. Lack of familiarity of villagers with solar energy systems, costly creation of technical, scientific, and industrial potentials required for the implementation of these projects, instability in the process of current systems in the use of photovoltaic systems, and severe impact. One of the challenges of developing this type of energy is the reduction of allocated budgets.

The existence of 330 sunny days in Kerman is one of the main capacities of using local potentials for energy production in the country, which is being formed these days with government investments and domestic and foreign private sector. Iran is a good country to invest in solar energy, and due to the geographical location of Kerman and the number of sunny days, it has one of the most desirable places to develop solar energy projects. At present, it is possible to generate at least 2500 megawatts of electricity from the sun in Kerman, and with the investment of Afghans in Kerman, electricity can be generated in the province and transferred to the borders.

The 10 MW power plant in Kerman province in the Baft region was built on a 20 hectare land using specialized forces and fully localized equipment by the private sector, and today, 6 July 1998, it was connected to the country's national electricity network. By exploiting the mentioned power plant, the emission of 9598 tons of environmental pollutants will be prevented, and water consumption will be reduced by 3060 cubic meters per year. The 10-megawatt power plant also saves 3.95 million cubic meters of natural gas annually in the country's electricity generation process. Kerman province has the highest absorption of solar energy as one of the most potential provinces in the country, and thus far, $8 \mathrm{MW}$ solar power plants with a total capacity of $48.7 \mathrm{MW}$ have been built and put into operation in this province. In addition, thus far, 926 units of solar power plants with a capacity of $8228 \mathrm{~kW}$ have been installed in this province.

\subsection{Wind}

Iran has abundant wind resources. According to a wind map with the middle scale published in 2016, it is estimated that more than 10,000 MW of electricity generation from the wind farm in Iran. Average wind speed statistics in potential sites of wind farms in Iran the average wind speed situation in cities such as Khaf (Khorasan Razavi) is exceptional. Due to its special geographical location and being located in a low-pressure region compared to the high-pressure regions of the north and northwest, Iran in general in winter and summer in the direction of winds that blow in winter from the Atlantic Ocean and the Mediterranean Sea and Central Asia, which is located in the summer from the Indian Ocean and northwest to Iran. In Iran, $6500 \mathrm{MW}$ wind energy potential has been identified, with such a capacity, 19,900 GWh of electricity can be generated [76]. At present, there is a capacity to produce $660 \mathrm{~kW}$ wind turbines in Iran, which has reached the commercial stage. In the perspective of Iran's electricity industry, at the end of the fifth five-year plan of the country's industrial development, the estimated capacity of renewable energy power plants is about $2000 \mathrm{MW}$, most of which belongs to wind power plants [77].

Some of the windy areas in Iran are difficult to cross, and there are special conditions for some meteorological stations installed, the distance between the towers is high, the challenge of buying parts and equipment from European countries due to the increase in the euro against the rial are the main challenges. They are in the wind power industry in Iran. In addition, other issues such as sanctions against Iran for importing some parts and raw materials are other problems in the development of this energy. Of course, recent cases are improving with the increasing rate of domestic production, which makes the future of this energy brighter. Atlas map of Iran's wind speed is shown in Figure 12. 


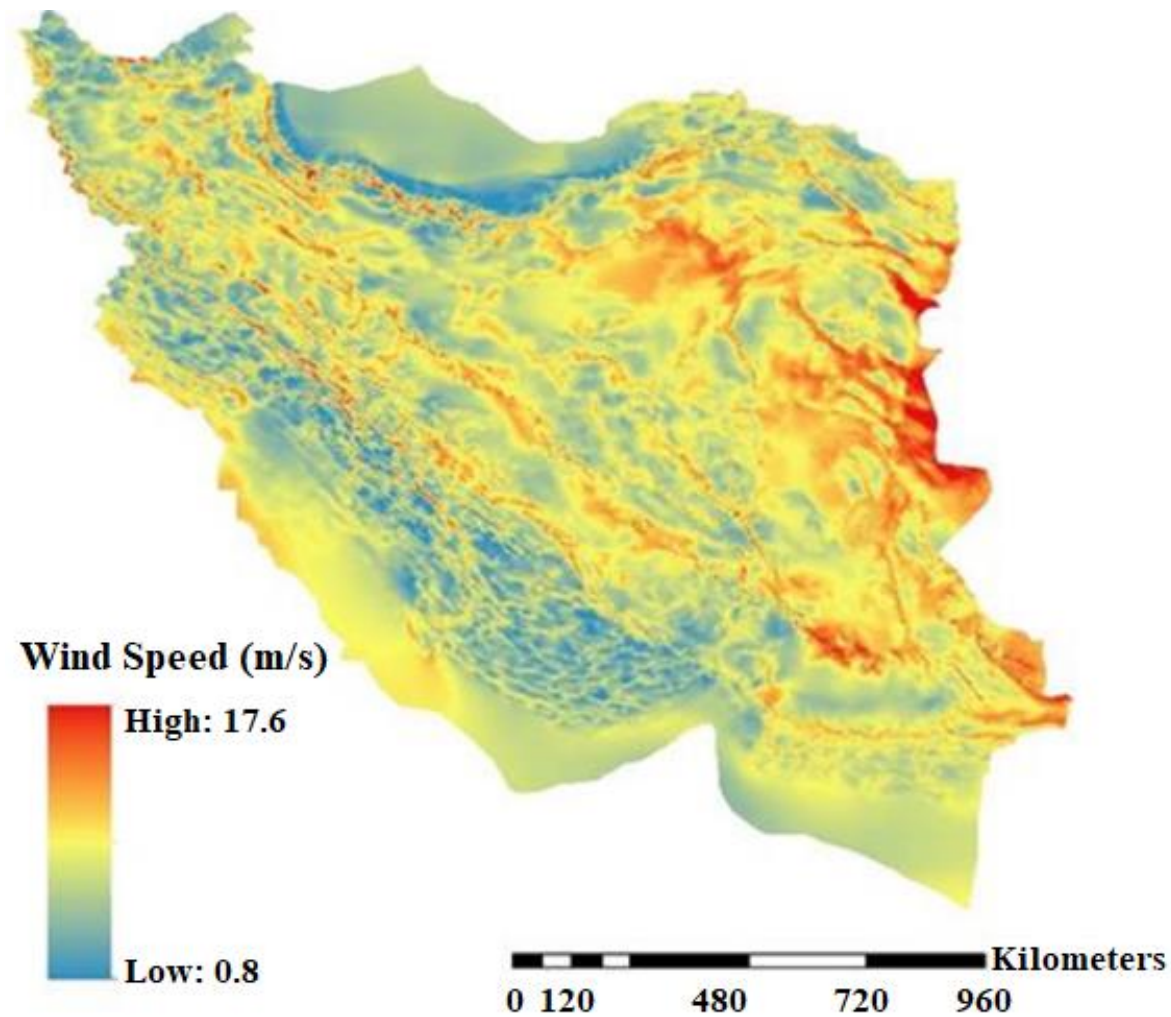

Figure 12. Atlas of the country's wind speed at the height of 50 (bottom) and $80 \mathrm{~m}$ (above) the ground (Adapted with permission from ref. [78,79] copyright 2015 Renewable and sustainable energy reviews).

\subsection{Geothermal}

Iran has favorable conditions for the formation of geothermal energy fields due to its location in the path of the earthquake belt and young volcanic activity. The existence of hot springs in the country proves this claim. Therefore, geothermal energy is one of the least expensive renewable energy options (in terms of production cost) for Iran. Unlike wind or solar, a geothermal power plant can provide baseload power and stability. Iran's total geothermal potential is estimated at about $500 \mathrm{MW}$ for instantaneous or singlephase steam cycles and up to 10 times higher for dual-cycle systems that require lower reservoir temperatures. However, the share of geothermal energy in the country's energy composition for the next 10-20 years is less than $200 \mathrm{MW}$. This is almost the estimated potential of Sabalan region located in the northwestern region of Iran, where exploratory drilling studies and resource evaluation studies in this region were completed. Production wells are being drilled for a five-megawatt pilot plant. Exploratory drilling has started in the other three areas of Damavand, Khoy, Mako, and Sahand, and preliminary studies are underway in the other 10 areas.

Problems with opening letters of credit, sanctions on Iran for drilling goods and equipment, as well as weather conditions that in some cases cause delays in work are among the obstacles that face this type of energy. The distribution of different geothermal energy sources in Iran is shown in Figure 13.

It is predicted that there are over 200 geothermal regions in our country, but they are not available in a codified and accurate form. Thus, we must move quickly in this area to make up for past delays thus that we do not lag behind the countries in the region in this area. Turkey is leading the way in the use of geothermal resources, as well as Saudi Arabia, which, such as Iran, has oil reserves but is considering using this energy and is preparing a geothermal atlas of their country. Recently, 12 geothermal zones were identified in west AzarBayjan. 


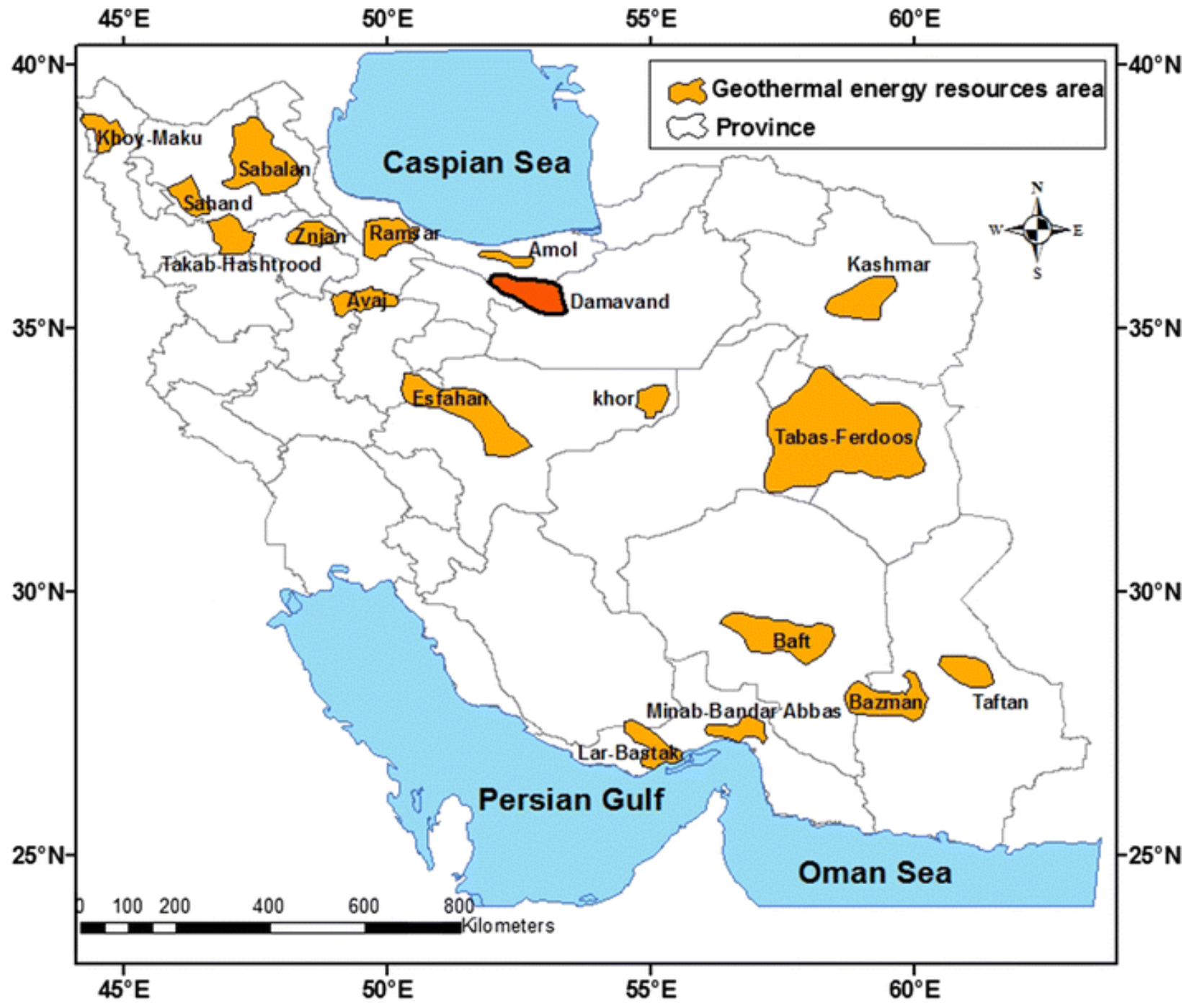

Figure 13. Distribution of different geothermal energy sources in the country (Reprinted with permission from ref. [80] copyright 2019 Geothermics).

\subsection{Hydropower}

Hydropower accounts for $13.8 \%$ of the national electricity generation and $4.98 \%$ of the total electricity generated in Iran. Hydroelectricity, on the other hand, accounts for about $19 \%$ of the total electricity generated in the world. Karun 3 hydropower plant with a capacity of $2280 \mathrm{MW}$ of electricity and annual production of $4170 \mathrm{GWh}$ is the largest hydropower plant in the country. At present, there is about $11.3 \mathrm{GW}$ of hydropower generation capacity in the whole country. From 1387 to 1394,5 to $13.5 \mathrm{GWh}$ of hydropower energy has been produced in the country. Iran, with an average rainfall equal to one-third of the world average, is one of the arid and semi-arid countries in the world, and in addition, perhaps the most important reason for the establishment of dams in Iran is the inadequate temporal and spatial distribution of rainfall. This means, firstly, that a measure must be taken to store water for the time required for agriculture and drinking, and secondly, that it deviates significantly from the spatial standard of rainfall in the country. Figure 14 shows the map of hydropower energy sources in Iran. 


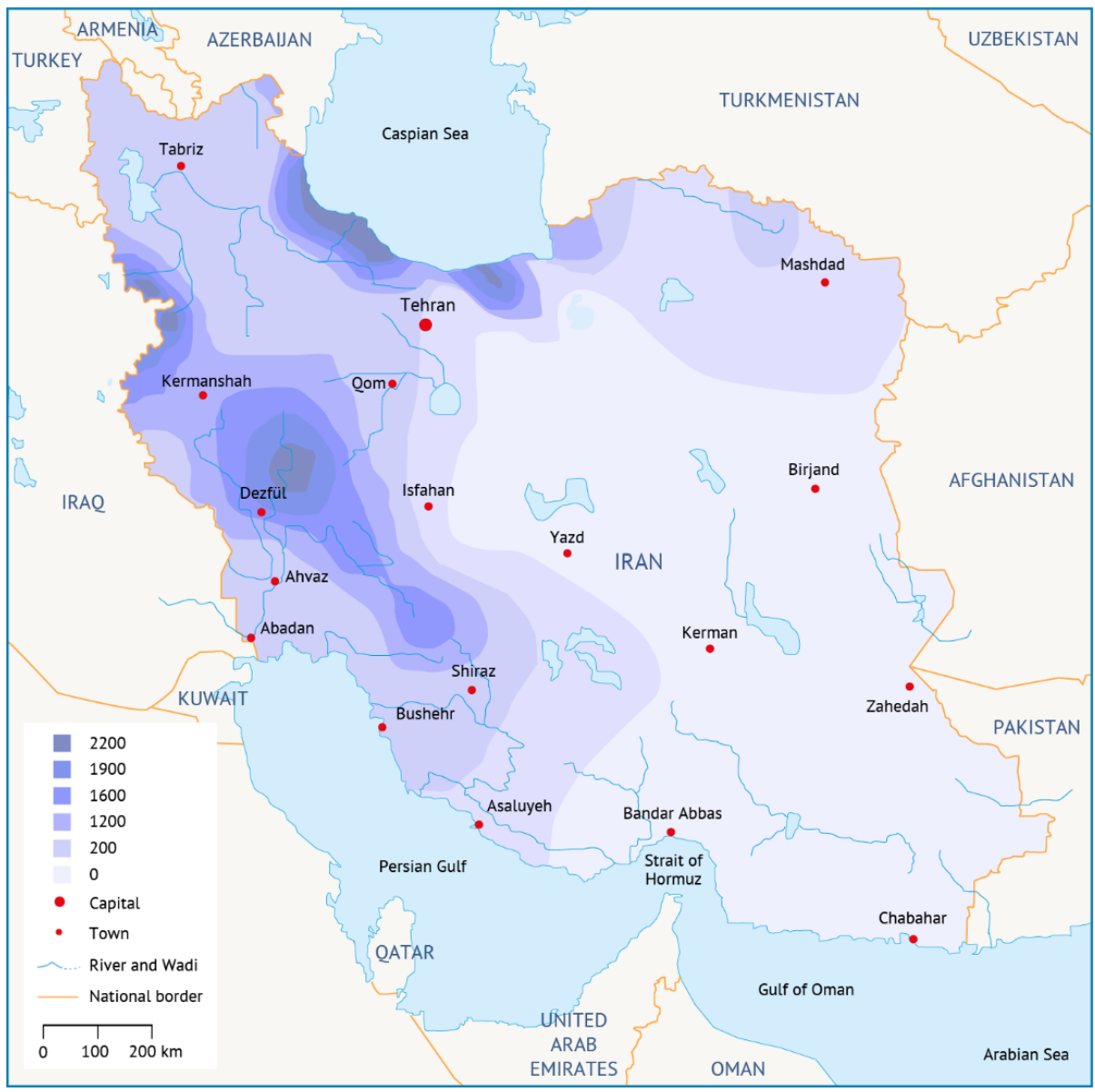

Figure 14. Distribution of different Hydropower energy sources in the country (Reprinted with permission from ref. [81] copyright 2018 Energy).

\subsection{Biomass}

The vast country of Iran is relatively rich in biomass resources. The use of biomass in Iran has traditionally been high before the wide distribution of petroleum products in 1338, but after the mentioned date, its use has decreased. The first digester of methane production in Iran was built in the Niazabad village of Lorestan in 1975. According to the results of the 1996 census, five percent of rural households used biomass resources for heating and cooking, respectively. Recently, a power plant with a nominal capacity of $650 \mathrm{~kW}$ has been inaugurated at the site of the old landfill in Mashhad with an initial investment of 15 billion rials. Biogas can be produced from animal waste available in Iran 8668 million cubic meters. Biogas can be produced from the mass of agricultural and forest wastes in Iran is 8.8 million cubic meters. Biogas from anaerobic treatment is about 200 million cubic meters. The biogas that can be produced from large food industries in the country is estimated at $280-80$ million cubic meters per year. By exploiting the anaerobic digestion process of perishable waste, a total of 2.7 million cubic meters of biogas can be produced in the country per year. It can be seen that only from the above sources, on average, 9 million cubic meters of biogas can be extracted annually [82].

Lack of encouragement of experts to localize resources and production of technical knowledge and the lack of a clear boundary between the activities of the public and private sectors are the main challenges for the development of biomass energy in Iran.

Hydrogen technology and fuel cell at present, hydrogen production projects are carried out by alkaline electrolysis and hydrogen storage methods, and by building fuel cell systems and connecting this complex to photovoltaic panels, the complete cycle of production, storage, and consumption of clean energy based on hydrogen is carried out. 
In any case, given that Iran is the second-largest source of gas, the development of this technology in the near future is predictable.

However, there are limited consultants, contractors, and competent supervisors in the field of hydrogen and fuel cell technologies, advanced technologies related to the production process, storage, and consumption of hydrogen, as well as problems arising from international sanctions from obstacles that have slowed the development of this technology.

Given the complex and evolutionary process of renewable energy development, it is essential to have a framework for its governance. Management of the transition to renewable energy can be conceptually divided into two stages, namely systemic analysis and policymaking. The article by Moalemi et al. focused on identifying the different methodological stages in the system analysis stage [83]. These steps provide the necessary input for the second stage of policymaking by gaining a clear understanding of the current situation. In the first step, the boundaries of the transfer process are determined by specifying the unit of analysis and identifying the components and relationships of the system. In the second stage, to have a big picture of the evolution of the system, the dynamics of technology development over time are drawn. In the third stage, by comparing different approaches and choosing the most appropriate method, an approach for analysis and sustainability transfer policy is selected. Finally, all these methodological steps in the Iranian Fuel Cell Technology Development Program are used to demonstrate the practicality of the proposed conceptual framework in a real problem and provide insights for employees. The biomass and biogas energy sources of the country are shown in Figure 15.

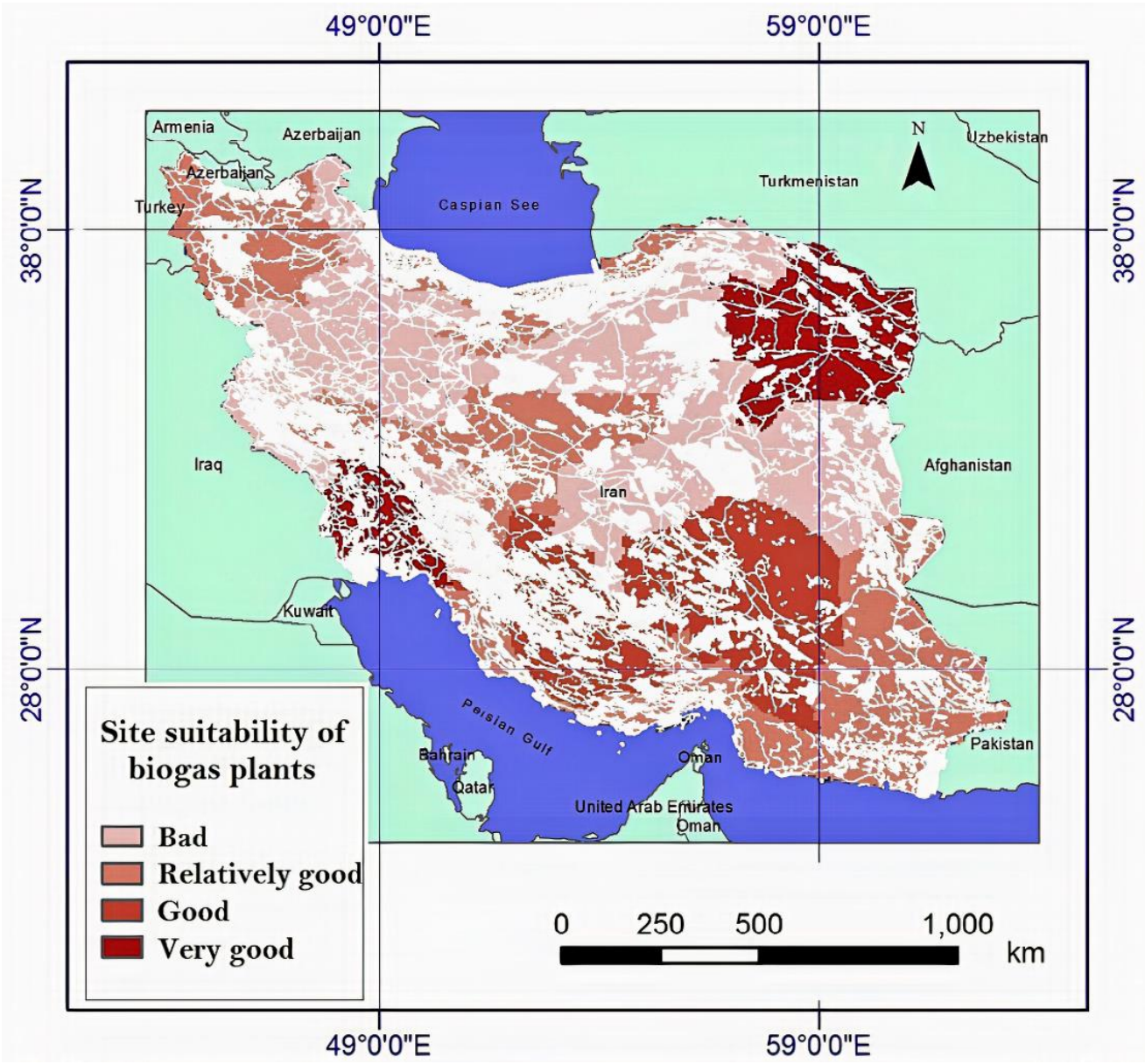

Figure 15. Distribution and potential measurement of biomass energy sources in Iran (Adapted with permission from ref. [84] copyright 2020 Renewable Energy). 


\section{Conclusions}

Regarding the lack of sufficient data in order to demonstrate comprehensive, integrated policies for the use of renewable energy supply systems in Iran, this study, using a review methodology, investigated current and future energy demands and existing renewable energy resource policies in Iran by employing the latest available data from the Ministry of Energy, Ministry of Petroleum and national laws and documents. Then, the strategic analysis estimated the direction of relationships among considered variables.

The experiences of different countries and the comparative studies conducted in the present project indicate that no single set of policies can successfully create a renewable energy industry in any country, both operationally and financially. However, it seems that many concerns such as the emission of pollution, especially carbon dioxide, access to resources, the cost of fossil fuels, security of supply, and the impact on foreign exchange have led to an environment of high interest in the development of renewable energy sources globally Arise.

Iran's extractable gas resources are so vast that it is very difficult to justify the use of more expensive energy sources for the future. Resource depletion is not currently a challenge. However, in the near future, this decline may be particularly significant at the level of national policy, especially for oil. Perhaps for Iran, the decision to move towards the use of renewable energy sources is more than an absolute necessity, it is to diversify electricity generation.

Previous studies have shown that there are relatively rich sources of renewable energy in our country. However, for economic reasons and to ensure sufficient competition, it seems that the position of wind energy in Iran is higher than other renewable energy sources and has a higher priority in the short or medium term. The wind turbine market in Iran is far from the competitive pressures of wind turbine manufacturers and its domestic and foreign components, and the indirect transfer of technology through the exchange of human resources with other international wind energy institutions and enterprises does not exist or is very low. Wind turbine towers also seem to be supplied from within.

These two components together make up $25 \%$ of the value of a normal wind turbine, and this rate of domestic production is relatively high for the current size of the Iranian market. According to the analysis performed by SANA [85], another $25 \%$, which includes other equipment and parts, is also produced domestically. A total of $50 \%$ of domestic production is very high and close to the level reached by the first wind turbine manufacturing industries in Denmark and Germany. Of course, the technical and commercial risks are relatively high, even for high-volume production.

Having sufficient and appropriate expertise in the form of experienced engineers for the development of wind technology in the factory is necessary for all turbine factories and component manufacturers. It is also necessary to conduct wider planning for the construction of wind farms in the country with the help of experiences and information obtained from the implementation of pilot projects.

Concentrated solar-thermal power plants (CSPs) are much more expensive than other renewable energy sources and should be given less priority for short- or medium-term investment. Nevertheless, given Iran's position in the CSP global solar belt, it may become the most important source of renewable energy in the long run. Therefore, Iran should continue the current plans for domestic manufacturers of CSP parts and equipment with the aim of reducing parts costs, improving current products, and expanding the types of parts produced.

Using solar energy to supply hot water to homes and industrial centers is one of the most cost-effective ways to use solar energy in oil-burning villages in Iran. For scattered users far from the grid who need relatively little power, photovoltaics is almost a competitive or low-cost technology. Photovoltaic has a strong and modular structure and requires little maintenance, and is, therefore, very suitable for remote rural users. For older users, it seems best to hybridize with wind or fossil fuels. 
Due to the relatively longer duration of operation of geothermal projects compared to other renewable energy sources, the location of a large number of identified areas that require long transmission lines and very high investment costs provide limited contracting and development capacity for contractors. Internationally, in the short term, Iran should pursue a strategy of gradual development in this area, the primary goal of which is domestic capacity building. It is clear that high-temperature identified tanks relatively close to the grid connection points should be given priority in development and the development of tanks that are more suitable for dual-cycle power plants and require higher costs should be delayed.

In villages and small towns that are impassable and dilapidated, where energy delivery is not cost-effective, the construction of a biogas plant is preferable. For example, the southern regions of Khorasan and Sistan and Baluchestan, because the winds of the region are only 4 days and the sandstorm scratch the solar collectors, the development of wind and solar energy is not possible. In addition, the use of biogas energy is very useful and correct for the dense villages of the western regions of the country and the villages of the north of the country that have cold winters and are going through difficult conditions. The biggest obstacle to the commercial development of this industry in Iran is the conditions of landfills. As mentioned before, before any investment is made, basic activities must be conducted to upgrade all landfill sites to meet the requirements of health landfills. Unhygienic landfills that are not properly managed and do not collect treated fluids can contaminate the surrounding soil and groundwater aquifers and cause irreparable damage to public health.

Municipalities should be encouraged to implement and complete their landfills due to environmental issues and public health goals. On the other hand, sufficient information about the actual amount of waste in certain areas, waste composition, age, humidity, temperature, $\mathrm{pH}$, and other necessary factors.

Assuming the abundance of natural gas supply in Iran, even though this technology consumes fossil fuels, the capacity of the fuel cell program in Iran's work program is appropriate. Domestic natural gas markets can be significantly expanded by future applications of fuel cells in power generation and transmission. Today, natural gas passing through a reformer is the main source of hydrogen in most fuel cell installations.

Wind energy, solar energy, geothermal energy, biomass energy, and hydropower in our country have very good and non-polluting sources, each of which can provide us with very large amounts of energy. Therefore, it is hoped that policymakers in this field will take greater steps to support, encourage, and develop these clean resources in Iran.

Renewable energy has caused the employment of 43,450 people directly and indirectly in the country and the volume of non-governmental investment in this sector has reached more than 124,000 billion rials.

From July 2009 to the beginning of June 2016, three billion and 132 million kilowatt hours of energy was produced from renewable sources, which this amount of electricity generation from renewable energy could reduce the emission of about two million and 161 thousand tons of greenhouse gases.

In addition, this amount of new energy production has reduced 889 million cubic meters of fossil fuel consumption in Iran, which is one of the main causes of air pollution in the country, and more than 689 million liters of water has been saved.

Currently, $416 \mathrm{MW}$ of renewable power plants are under construction in the country, and the installed capacity of the country's new energy has reached $724 \mathrm{MW}$.

Thus far, 103 MW renewable power plants have been installed in the country and another $42 \mathrm{MW}$ power plants are under construction.

A review of the figures in this section indicates that $44 \%$ of the country's renewable power plants are solar, $40 \%$ wind, $13 \%$ small hydropower, $2 \%$ heat recovery, and $1 \%$ is biomass.

Soon, Iran will be able to supply a significant percentage of its electricity through renewable energy sources. Iran has a high climatic diversity and of the four types of climate 
in the world, four types are available in Iran, which has increased the potential for the use of renewable energy.

Funding: This research received no external funding.

Data Availability Statement: Datasets analyzed during the current study are available and can be given following a reasonable request from the corresponding author.

Conflicts of Interest: The authors declare no conflict of interest.

\section{References}

1. World Energy Council. World Renewable Energy Report; World Energy Council: London, UK, 2015.

2. BBE. Outlook; BP: London, UK, 2018.

3. Dale, S.; Fattouh, B. Peak oil demand and long-run oil prices. Energy Insight 2018, 25, 2-11.

4. Weijermars, R.; Clint, O.; Pyle, I. Competing and partnering for resources and profits: Strategic shifts of oil Majors during the past quarter of a century. Energy Strategy Rev. 2014, 3, 72-87. [CrossRef]

5. Bloomberg, N. World Reaches 1000 GW of Wind and Solar, Keeps Going. 2018. Available online: https://about.bnef.com/blog/ world-reaches-1000gw-wind-solar-keeps-going (accessed on 2 November 2021).

6. Alizadeh, R.; Soltanisehat, L.; Lund, P.D.; Zamanisabzi, H. Improving renewable energy policy planning and decision-making through a hybrid MCDM method. Energy Policy 2020, 137, 111174. [CrossRef]

7. Morea, D.; Poggi, L.A. Islamic finance and renewable energy: An innovative model for the sustainability of investments. In Proceedings of the 2016 AEIT International Annual Conference (AEIT), Capri, Italy, 5-7 October 2016; pp. 1-7.

8. World Energy Council. World Energy Resources; World Energy Council: London, UK, 2013.

9. Belmonte, S.; Núñez, V.; Viramonte, J.G.; Franco, J. Potential renewable energy resources of the Lerma Valley, Salta, Argentina for its strategic territorial planning. Renew. Sustain. Energy Rev. 2009, 13, 1475-1484. [CrossRef]

10. Raturi, A.K. Renewables 2016 Global Status Report. 2016. Available online: https://www.ren21.net/gsr-2016/ (accessed on 9 April 2020).

11. Atalay, Y.; Kalfagianni, A.; Pattberg, P. Renewable energy support mechanisms in the Gulf Cooperation Council states: Analyzing the feasibility of feed-in tariffs and auction mechanisms. Renew. Sustain. Energy Rev. 2017, 72, 723-733. [CrossRef]

12. Abdmouleh, Z.; Alammari, R.A.; Gastli, A. Recommendations on renewable energy policies for the GCC countries. Renew. Sustain. Energy Rev. 2015, 50, 1181-1191. [CrossRef]

13. Poudineh, R.; Sen, A.; Fattouh, B. Advancing renewable energy in resource-rich economies of the MENA. Renew. Energy 2018, 123, 135-149. [CrossRef]

14. Kreiss, J.; Ehrhart, K.-M.; Haufe, M.-C. Appropriate design of auctions for renewable energy support-Prequalifications and penalties. Energy Policy 2017, 101, 512-520. [CrossRef]

15. Ghouchani, M.; Taji, M.; Cheheltani, A.S.; Chehr, M.S. Developing a perspective on the use of renewable energy in Iran. Technol. Forecast. Soc. Chang. 2021, 172, 121049. [CrossRef]

16. Solaymani, S. A review on energy and renewable energy policies in Iran. Sustainability 2021, 13, 7328. [CrossRef]

17. Afsharzade, N.; Papzan, A.; Ashjaee, M.; Delangizan, S.; van Passel, S.; Azadi, H. Renewable energy development in rural areas of Iran. Renew. Sustain. Energy Rev. 2016, 65, 743-755. [CrossRef]

18. Fadai, D.; Esfandabadi, Z.S.; Abbasi, A. Analyzing the causes of non-development of renewable energy-related industries in Iran. Renew. Sustain. Energy Rev. 2011, 15, 2690-2695. [CrossRef]

19. Gillingham, K.; Newell, R.G.; Palmer, K. Energy efficiency economics and policy. Annu. Rev. Resour. Econ. 2009, 1, 597-620. [CrossRef]

20. Nejat, P.; Jomehzadeh, F.; Taheri, M.M.; Gohari, M.; Majid, M.Z.A. A global review of energy consumption, $\mathrm{CO}_{2}$ emissions and policy in the residential sector (with an overview of the top ten $\mathrm{CO}_{2}$ emitting countries). Renew. Sustain. Energy Rev. 2015, 43, 843-862. [CrossRef]

21. Uzaman, S.K.; Shuja, J.; Maqsood, T.; Rehman, F.; Mustafa, S. A systems overview of commercial data centers: Initial energy and cost analysis. Int. J. Inf. Technol. Web Eng. (IJITWE) 2019, 14, 42-65. [CrossRef]

22. Peng, H.-g.; Shen, K.-w.; He, S.-s.; Zhang, H.-y.; Wang, J.-q. Investment risk evaluation for new energy resources: An integrated decision support model based on regret theory and ELECTRE III. Energy Convers. Manag. 2019, 183, 332-348. [CrossRef]

23. Zahedi, R.; Ahmadi, A.; Dashti, R. Energy, exergy, exergoeconomic and exergoenvironmental analysis and optimization of quadruple combined solar, biogas, SRC and ORC cycles with methane system. Renew. Sustain. Energy Rev. 2021, 150, 111420. [CrossRef]

24. Moosavian, S.F.; Zahedi, R.; Hajinezhad, A. Economic, Environmental and Social Impact of Carbon Tax for Iran: A Computable General Equilibrium Analysis. Energy Sci. Eng. 2022, 10, 13-29. [CrossRef]

25. Pelay, U.; Luo, L.; Fan, Y.; Stitou, D.; Rood, M. Thermal energy storage systems for concentrated solar power plants. Renew. Sustain. Energy Rev. 2017, 79, 82-100. [CrossRef]

26. Saiffodin, A.; Moosavian, S.F. Impact of Climate Change on Economic and Environmental Performance of Wind Turbine Based on Life Cycle Assessment Method. Modares Mech. Eng. 2021, 21, 835-848. 
27. Morea, D.; Bittucci, L.; Cafaro, A.; Mango, F.; Murè, P. Can the Current State Support Mechanisms Help the Growth of Renewable Energies in Wind Markets? Sustainability 2021, 13, 12094. [CrossRef]

28. Campisi, D.; Gitto, S.; Morea, D. Effectiveness of incentives for wind energy: Models and empirical evidences from an Italian case study. J. Sustain. Sci. Manag. 2016, 11, 39-48.

29. Zahedi, R.; Ahmadi, A.; Gitifar, S. Reduction of the environmental impacts of the hydropower plant by microalgae cultivation and biodiesel production. J. Environ. Manag. 2022, 304, 114247. [CrossRef] [PubMed]

30. Zhang, J.; Lu, J.; Pan, J.; Tan, Y.; Cheng, X.; Li, Y. Implications of the development and evolution of global wind power industry for China-An empirical analysis is based on public policy. Energy Rep. 2022, 8, 205-219. [CrossRef]

31. Gao, C.; Sun, M.; Geng, Y.; Wu, R.; Chen, W. A bibliometric analysis based review on wind power price. Appl. Energy 2016, 182, 602-612. [CrossRef]

32. Lichtenegger, G.; Rentizelas, A.A.; Trivyza, N.; Siegl, S. Offshore and onshore wind turbine blade waste material forecast at a regional level in Europe until 2050. Waste Manag. 2020, 106, 120-131. [CrossRef]

33. Zahedi, R.; Ahmadi, A.; Sadeh, M. Investigation of the load management and environmental impact of the hybrid cogeneration of the wind power plant and fuel cell. Energy Rep. 2021, 7, 2930-2939. [CrossRef]

34. Atabi, F. Renewable energy in Iran: Challenges and opportunities for sustainable development. Int. J. Environ. Sci. Technol. 2004, 1, 69-80. [CrossRef]

35. Melikoglu, M. Geothermal energy in Turkey and around the World: A review of the literature and an analysis based on Turkey's Vision 2023 energy targets. Renew. Sustain. Energy Rev. 2017, 76, 485-492. [CrossRef]

36. Daneshgar, S.; Zahedi, R. Investigating the hydropower plants production and profitability using system dynamics approach. $J$. Energy Storage 2022, 46, 103919. [CrossRef]

37. Corera, G. Shopping for Bombs: Nuclear Proliferation, Global Insecurity, and the Rise and Fall of the AQ Khan Network; Oxford University Press: Oxford, UK, 2009.

38. Rubanenko, O.; Yanovych, V.; Miroshnyk, O.; Danylchenko, D. Hydroelectric power generation for compensation instability of non-guaranteed power plants. In Proceedings of the 2020 IEEE 4th International Conference on Intelligent Energy and Power Systems (IEPS), Istanbul, Turkey, 7-11 September 2020; pp. 52-56.

39. Zahedi, R.; Daneshgar, S. Exergy analysis and optimization of Rankine power and ejector refrigeration combined cycle. Energy 2022, 240, 122819. [CrossRef]

40. Scarlat, N.; Dallemand, J.-F.; Fahl, F. Biogas: Developments and perspectives in Europe. Renew. Energy 2018, 129, 457-472. [CrossRef]

41. Dodds, P.E.; Staffell, I.; Hawkes, A.D.; Li, F.; Grünewald, P.; McDowall, W.; Ekins, P. Hydrogen and fuel cell technologies for heating: A review. Int. J. Hydrog. Energy 2015, 40, 2065-2083. [CrossRef]

42. Daneshgar, S.; Zahedi, R. Optimization of power and heat dual generation cycle of gas microturbines through economic, exergy and environmental analysis by bee algorithm. Energy Rep. 2022, 8, 1388-1396. [CrossRef]

43. Birkland, T.A. After Disaster: Agenda Setting, Public Policy, and Focusing Events; Georgetown University Press: Washington, DC, USA, 1997.

44. Grieve, J. A Corpus-Based Regional Dialect Survey of Grammatical Variation in Written Standard American English; Northern Arizona University: Flagstaff, AZ, USA, 2009.

45. Bakhteeyar, H.; Maleki, A. Development of two intelligence-based scenarios for prediction of future natural gas consumption. J. Sci. Res. Dev. 2015, 2, 158-166.

46. El-Katiri, L. A Roadmap for Renewable Energy in the Middle East and North Africa; Oxford Institute for Energy Studies: Oxford, UK, 2014.

47. Oxenstierna, S.; Tynkkynen, V.-P. Russian Energy and Security up to 2030; Routledge: London, UK, 2014.

48. Ahmed, R.; Mustafa, U. Impact of CPEC projects on agriculture sector of Pakistan: Infrastructure and agricultural output linkages Pak. Dev. Rev. 2016, 2016, 511-527.

49. Ali, H.; Asgher, M.T. The Role of the Sectoral Composition of Foreign Direct Investment on Economic Growth: A Policy Proposal for CPEC and Regional Partners. Pak. Dev. Rev. 2016, 2016, 89-103.

50. Khan, M.A. Modelling and forecasting the demand for natural gas in Pakistan. Renew. Sustain. Energy Rev. 2015, 49, 1145-1159. [CrossRef]

51. Perwez, U.; Sohail, A. Forecasting of Pakistan's net electricity energy consumption on the basis of energy pathway scenarios. Energy Procedia 2014, 61, 2403-2411. [CrossRef]

52. Kazmi, S.T.H. China's Journey in Renewable Energy and Its Potential Spillover Effects through the CPEC in Pakistan. Pak. Dev. Rev. 2016, 2016, 619-631.

53. Meier, A.; Rosenfeld, A.H.; Wright, J. Supply curves of conserved energy for California's residential sector. Energy 1982, 7, 347-358. [CrossRef]

54. Fallahi, A.; Ebrahimi, R.; Ghaderi, S. Measuring efficiency and productivity change in power electric generation management companies by using data envelopment analysis: A case study. Energy 2011, 36, 6398-6405. [CrossRef]

55. Yadav, V.K.; Padhy, N.; Gupta, H. A micro level study of an Indian electric utility for efficiency enhancement. Energy 2010, 35, 4053-4063. [CrossRef] 
56. Blomberg, J.; Henriksson, E.; Lundmark, R. Energy efficiency and policy in Swedish pulp and paper mills: A data envelopment analysis approach. Energy Policy 2012, 42, 569-579. [CrossRef]

57. Forsstroem, J.; Lahti, P.; Pursiheimo, E.; Raemae, M.; Shemeikka, J.; Sipilae, K.; Tuominen, P.; Wahlgren, I. Measuring Energy Efficiency: Indicators and Potentials in Buildings, Communities and Energy Systems; VTT Technical Research Centre of Finland: Espoo, Finland, 2011; 112p.

58. Teske, S.; Sawyer, S.; Schäfer, O. Energy [r] evolution: A Sustainable World Energy Outlook 2015: 100\% Renewable Energy for All; Greenpeace International: Amsterdam, The Netherlands, 2015.

59. Elkington, J.; Trisoglio, A. Developing realistic scenarios for the environment: Lessons from Brent Spar. Long Range Plan. 1996, 29, 762-769. [CrossRef]

60. Masih, A.M.; Masih, R. Energy consumption, real income and temporal causality: Results from a multi-country study based on cointegration and error-correction modelling techniques. Energy Econ. 1996, 18, 165-183. [CrossRef]

61. Inglesi, R. Aggregate electricity demand in South Africa: Conditional forecasts to 2030. Appl. Energy 2010, 87, 197-204. [CrossRef]

62. Raza, S.A.; Shahbaz, M.; Nguyen, D.K. Energy conservation policies, growth and trade performance: Evidence of feedback hypothesis in Pakistan. Energy Policy 2015, 80, 1-10. [CrossRef]

63. Zahedi, R.; Rad, A.B. Numerical and experimental simulation of gas-liquid two-phase flow in 90-degree elbow. Alex. Eng. J. 2021, 61, 2536-2550. [CrossRef]

64. Hosseini, S.E.; Andwari, A.M.; Wahid, M.A.; Bagheri, G. A review on green energy potentials in Iran. Renew. Sustain. Energy Rev. 2013, 27, 533-545. [CrossRef]

65. Davenport, K. Iran dismantling centrifuges, iaea says. Arms Control Today 2015, 45, 24.

66. Borzuei, D.; Moosavian, S.F.; Ahmadi, A. Investigating the dependence of energy prices and economic growth rates with emphasis on the development of renewable energy for sustainable development in Iran. Sustain. Dev. 2022. [CrossRef]

67. Dehkordi, M.K.; Kohestani, H.; Yadavar, H.; Roshandel, R.; Karbasioun, M. Implementing conceptual model using renewable energies in rural area of Iran. Inf. Process. Agric. 2017, 4, 228-240. [CrossRef]

68. Tofigh, A.A.; Abedian, M. Analysis of energy status in Iran for designing sustainable energy roadmap. Renew. Sustain. Energy Rev. 2016, 57, 1296-1306. [CrossRef]

69. Kriegler, E.; O’Neill, B.C.; Hallegatte, S.; Kram, T.; Lempert, R.J.; Moss, R.H.; Wilbanks, T. The need for and use of socio-economic scenarios for climate change analysis: A new approach based on shared socio-economic pathways. Glob. Environ. Chang. 2012, 22, 807-822. [CrossRef]

70. Aghahosseini, A.; Bogdanov, D.; Ghorbani, N.; Breyer, C. Analysis of 100\% renewable energy for Iran in 2030: Integrating solar PV, wind energy and storage. Int. J. Environ. Sci. Technol. 2018, 15, 17-36. [CrossRef]

71. Khonsari, A. Briefing Renewable Energy in Iran; Technical Report; Watson Farley and Williams LLP: London, UK, 2016.

72. Marefati, M.; Mehrpooya, M.; Shafii, M.B. Optical and thermal analysis of a parabolic trough solar collector for production of thermal energy in different climates in Iran with comparison between the conventional nanofluids. J. Clean. Prod. 2018, 175, 294-313. [CrossRef]

73. Hirbodi, K.; Enjavi-Arsanjani, M.; Yaghoubi, M. Techno-economic assessment and environmental impact of concentrating solar power plants in Iran. Renew. Sustain. Energy Rev. 2020, 120, 109642. [CrossRef]

74. Shorabeh, S.N.; Firozjaei, M.K.; Nematollahi, O.; Firozjaei, H.K.; Jelokhani-Niaraki, M. A risk-based multi-criteria spatial decision analysis for solar power plant site selection in different climates: A case study in Iran. Renew. Energy 2019, 143, 958-973. [CrossRef]

75. Enjavi-Arsanjani, M.; Hirbodi, K.; Yaghoubi, M. Solar energy potential and performance assessment of CSP plants in different areas of Iran. Energy Procedia 2015, 69, 2039-2048.

76. Mostafaeipour, A. Feasibility study of harnessing wind energy for turbine installation in province of Yazd in Iran. Renew. Sustain. Energy Rev. 2010, 14, 93-111. [CrossRef]

77. Zahedi, R.; Ghorbani, M.; Daneshgar, S.; Gitifar, S.; Qezelbigloo, S. Potential measurement of Iran's western regional wind energy using GIS. J. Clean. Prod. 2022, 330, 129883. [CrossRef]

78. Pishgar-Komleh, S.; Keyhani, A.; Sefeedpari, P. Wind speed and power density analysis based on Weibull and Rayleigh distributions (a case study: Firouzkooh county of Iran). Renew. Sustain. Energy Rev. 2015, 42, 313-322. [CrossRef]

79. Moradi, S.; Yousefi, H.; Noorollahi, Y.; Rosso, D. Multi-criteria decision support system for wind farm site selection and sensitivity analysis: Case study of Alborz Province, Iran. Energy Strategy Rev. 2020, 29, 100478. [CrossRef]

80. Yousefi, H.; Roumi, S.; Ármannsson, H.; Noorollahi, Y. Cascading uses of geothermal energy for a sustainable energy supply for Meshkinshahr City, Northwest, Iran. Geothermics 2019, 79, 152-163. [CrossRef]

81. Ifaei, P.; Farid, A.; Yoo, C. An optimal renewable energy management strategy with and without hydropower using a factor weighted multi-criteria decision making analysis and nation-wide big data-Case study in Iran. Energy 2018, 158, $357-372$. [CrossRef]

82. Maghanaki, M.M.; Ghobadian, B.; Najafi, G.; Galogah, R.J. Potential of biogas production in Iran. Renew. Sustain. Energy Rev. 2013, 28, 702-714. [CrossRef]

83. Moallemi, E.A.; Ahamdi, A.; Afrazeh, A.; Moghaddam, N.B. Understanding systemic analysis in the governance of sustainability transition in renewable energies: The case of fuel cell technology in Iran. Renew. Sustain. Energy Rev. 2014, 33, 305-315. [CrossRef] 
84. Samadi, S.H.; Ghobadian, B.; Nosrati, M. Prediction and estimation of biomass energy from agricultural residues using air gasification technology in Iran. Renew. Energy 2020, 149, 1077-1091. [CrossRef]

85. Report of the New Energy Organization in Iran; New Energy Organization: Tehran, Iran, 2015. 